\title{
REBELIONES ANDINAS ANTICOLONIALES. NUEVA GRANADA, PERU Y CHARCAS ENTRE EL SIGLO XVIII Y EL XIX *
}

En el presente ensayo quisiera analizar, simultáreamente, tres movimientos sociales que cobraron definición en el espacio andino entre 1765 y 1781 . Es decir, durante la puesta en práctica de las Reformas Borbónicas. Esta será precisamente la coyuntura cohesionadora que nos permitirá realizar comparaciones, al margen de posibles anacronismos. Me interesa abordar, concretamente, la rebelión de los barrios de Quito de 1765, la gran rebelión o rebelión de Túpac Amaru de 1780-1781 en el Bajo y el Alto Perú, y la rebelión de los Comuneros del Socorro en Nueva Granada, durante 1781.

Quisiera poder plantear dos tipos de preguntas. En la primera parte, confrontar algunos argumentos que han venico desarrollándose durante los últimos años en torno a este período de intranquilidad social. Dentio de esta línea de aná: lisis quisiera revisar algunas afirmaciones que juzgo tan sugerentes como controvertidas. Me refiero, por ejemplo, a la falta se consenso que se advierte cuando se intenta catalogar como rebeliones o revoluciones a este conjunto de movimientos; al planteamiento de que estas rebeliones de envergadura suponen consistentemente la culminación de revueltas menores; a la presencia o ausencia de rasgos mesiánicos en las mismas; al marco interpretativo de la Era de las Insurrecciones Andiras; y, finalmente, a la tesis de la Utopía Andina.

En una segunda parte quisiera poder concentrarme en las características particulares $d \epsilon$ los tres movimientos enun-

* Ponencia presentada en la Conferencia Anual de la Asociación de Historiadores Americanos (AHA), Sesión de Estudios Coloniales Latinonmericanos (CLAH). New York, diciembre 1990. 
ciados y confrontar algunas variables que funcionan en unos, pero no en otros o que adquieren, en todo caso, connotaciones particulares. Me refiero a la presencia de ciertos elementos que dotan a los movimientos de cohesión tales como el liderazgo de los caciques, el sistema de la mita, las minas y sus circuitos comerciales, las redes de parentesco; y a la de rasgos cesestabilizadores tales como la violencia cotidiana y la gue1 ra de castas.

Finalmente, trataré de proyectar los movimientos de la segunda mitad del siglo XVIII hacia las guerras de independencia del temprano XIX, circunscribiéndome a la primera fase de la lucha, que se materializó en el establecimiento de Juntas de Gobierno entre 1809-1814. Me interesa explorar hasta qué punto se puede hablar de un hilo conductor que sirva de nexo entre estos dos períodos y, en todo caso, a partir de qué mecanismos es que esta conexión se construye.

Primera Parte.

Los ARgumentos INTERPRETAtivos

\section{Rebeliones o Revoluciones}

Sobre la nomenclatura utilizada para definir a los movimientos sociales de este período, no existe un acuerdo entre los estudiosos. Para el caso de México, William Taylor nos habla de Rebeliones e Insurrecciones ${ }^{1}$. Para el caso de los Ancles, en un trabajo previo, he propuesto establecer una distinción entre Revueltas y Rebeliones ${ }^{2}$. Sin embargo, la coincidencia reside en que lo que Taylor denomina rebelión y yo

1 Taylor, William: Drinking, Homicide and Retellion in colonial Mexican Villages. Stanford, 1979. La versión en español ha sido publicada por el Fondo de Cultura Económica: Alcobolismo, Homicidio y Rebelión en México colonial, México, 1987.

2 O'Phelan Godoy, Scarlett: Rebellions and Revolts in Eighteenth century Peru cind Upper Perú, Colonia-Viena, 1985. Traducido bajo el títu:o de Un siglo de rebelioncs anticoloniales. Perú y Bolivia 1700-1783, Cusco, 1988. 
revuelta son movimientos menores mientras que lo que él define como insurrección y yo como rebelión, son movimienlos de mayor alcance. No obstante, en México, durante el siglo XVIII, no estalló una gran rebelión. Es decir, a diferencia de los Andes, no surgió un movimiento de envergacura suficiente que llegara a anudar la sucesión de rebeliones aispersas que se produjeron durante la segurida mitad del siglo XVIII, o que estuviera conformado por un liderazgo ctnicamente mixto capaz de elaborar un programa político que rcflejara los intereses de los distintos sectores sociales, y que comprometiera una extensa área geográfica durante un período prolongado de agitación social.

Sin embargo, a pesar de todas estas características particulares, insisto en que los movimientos de Quito, Perú y Nueva Granada caen dentro de la categoría de rebeliones y no de revoluciones. Si bien la naturaleza de la rebelión del sur andino es diferente, sobre todo en su segunda fase - en la fase aymara - resulta más conveniente definirla como gran rebelión que como revolución. Y no me refiero exclusivamente al hecho de que los insurgentes reafirmasen con insistencia su fdelidad al «Rey nuestro Señor», aunque, si hay un elemento común en los tres movimientos mencionados, éste sería la incompatibilidad que surge entre la figura del Rey, por un lado, y la del Mal Gobierno, por otro, al punto de hacerlos irreconciliables.

McFarlane nos habla de la rebelión de los barrios de Quito, Friede de la rebelión Comunera de Nueva Granada, Vilar de la gran rebelión o rebelión de Túpac Amaru ${ }^{3}$. No obstant $\epsilon$, en el libro de Phelan se plantea que el movimiento Comunero fue una revolución y un enfoque similar al que propone

3 McFarlane, Anthony: The Rebellion of the Barrios: Urban Insurrection in Bourbon Quito. «HAHR», núm. 69 2, 1989. Una versión prelininar del artículo aparece en el libro editado por John Fisher, Allan Kuethe y Anthony McFarlane: Reform and Insurrection in Bourbon New Granada and Peru, Louisiana, 1991. Friede, Juan: Rebelión Comunera de 1781. Documentos, Bogotá, 1981, 2 vols. Vilar, Pierre: La participación de las clases populares en los movimientos de Independencia en el Perú, en «La Independencia en el Perú», Lima, 1981 (segunda edición). 
Flores Galindo para el caso del movimiento Tupacamarista an los Andes ${ }^{4}$.

¿Que define una rebelión o una revolución? Básicamente la respuesta la encontramos en los programas políticos, en el nuevo tipo de sociedad que se esboza, en el nuevo tipo de gobierno que se propone. Pienso, siguiendo de alguna manera cl enfoque de J.C.D. Clark para el caso inglés " ${ }^{\text {, }}$ que el estado y la sociedad colonial del XVIII concibieron sus protestas dentro de un marco reformista de una naturaleza no-revolucionaria. Inclusive, los movimiento de Quito y Nueva Granada son lo suficientemente conservadores como para que las modificaciones o reformas que traía consigo el proyecto borbónico apareciesen como contraproducentes. Resulta entonces más apropiado hablar de rebeliones que de revoluciones. El comportamiento de las élites es similar: se oponen a un sistema impositivo que afecta a los productos en torno a los cuales giran sus intereses e inversiones. La consigna es impuestos versus libertad. Y, a diferencia de Quito, la élite de Socorro no atravesaba por una crisis productiva, lo cual, en cierta medida, empaña el argumento que recurre a la recesión económica para explicar la agitación social ". La fiscalidad representa un papel decisivo, no así la depresión económica. Desenmascarar los métodos de evasión fiscal a los que recurría la élite equivaldría a poner el dedo en la llaga.

En el caso de Quito esto es claro. Allí los criollos, élite y clero, dominan inicialmente la escena política ${ }^{\top}$. La rebelión de los barrios se desdobla, la población indígena y mestiza es más radical, pero el movimiento no deja de ser urba-

4 Phelan, John Leddy: The People and the King. The comunero Revolution in Colombia, 1781. Wisconsin, 1978. Flores Galindo, Alberto: Buscando un Inca, Lima, 1986. Capitulo III, «La Revolución Tupacamarista y los Pueblos Andinos».

5 Clark, J.C.D.: Revolution and Rebellion. State and society in England in the seventeenth and eighteenth centuries. Cambridge, 1986. La pregunta también se la plantea G. E. Aylmer en si. libro Rebellion or Revolution? England from Civil War to Restoration, Oxford, 1987.

6 Andrien, Kenneth: Economic crisis, taxes and the Quito Insurrection of 1765, «Past and Present», núm. 129, noviombre 1990, pág. 120.

7 Pérez, Joseph: Los movimientos precursores de la emancipación hispanoamericana, Madrid, 1982. McFarlane, Anthony: The Rebellion of the Barrios, págs. 287-300. 
no. El problema de monopolios y alcabalas atañe al sector urbano y a los propietarios de centros agropecuarios que residen en la capital. Las mitas y el tributo, que afectan a las masas indígenas del campo, no aparecen en las demandas iniciales aunque, irónicamente, los tributos se rezagan por siete tercios como corolario de la rebelión ".

En el caso de Nueva Granada - a esto se debe probablemente que Phelan utilice el término revolución- aparece la demanda por la tierra, por la abolición del tributo ${ }^{\ominus}$. Pero no es el argumento gravitante: la rebelión no surge a partir de estos conflictos sino que estalla en una provincia criolla y mestiza, en una provincia «blanca», para enfrentar monopolios y alcabalas. El movimiento se inicia con el asalto a la fábrica de aguardiente y a los almacenes de tabaco, productos que dentro del nuevo régimen fiscal quedaban estancados ${ }^{10}$. Incluso, no será el líder criollo Berbeo, sino el diri. gente mestizo Galán, quien tome la iniciativa de suspender el tributo aunque, finalmente, las capitulaciones de Zipaquirá liagan la concesión de reducirlo temporalmente, pero sin llegar a anularlo ${ }^{11}$. Cambios de carácter estructural, revoluciorario, habrían implicado tanto la erradicación total de tributos $\searrow$ mitas como transformaciones relevantes a nivel del agro. No ocurrió ni lo uno ni lo otro.

En el caso de la gran rebelión, particularmente en su fase temprana, la estructura interna del movimiento es un rctlejo de la sociedad de castas colonial; no hay, pues, modificaciones radicales. Los criollos se ubican en la esfera de las decisiones al lado del clan Túpac Amaru. Los caciques rebel-

8 Archivo General de Indias (en adelante, AGI), Audiencia de Quito, 2.289. Carta de Don Joseph Diguja, presidente de la Real Audiencia de Quito, fechada en 1768. Después de la Noche de San Juan, en que el pueblo se hace justicia por sus propias manos, se hablará de dar libertad a los esclavos y suspender el tributo indigena.

9 Phelan: The People and the King, pars. 89.94.

10 AGI, Indiferente General, 410. Sobre la tranquilización de las gentes de las villas de San Gil, Socorro, Tunja, Sogamoso, Duitama, Santa Rosa y demás pueblos sublevados. 1781.

11 Aguilera Peña, Mario: Los Comuneros: Guerra social y lucha anticolonial, Bogotá, 1985, pág. 118. Sobre el movimiento Comunero también se puede consultar el libro de Pinto Iss. cobar, Ines: La Rebelión del Común, Tunja, 1976. 
des y algunos mestizos de confianza tienen mando militar, los indios y los negros son la base de la pirámide social. No se advierten cambios sustanciales o inversiones notables de la pirámide pre-establecida. Entre las demandas, la supresión de iributos y mitas se ve postergada. Inclusive cuando se decreta su abolición, la ausencia de tributo y mita cubre exclusiramente el período en que la rebelión se mantiene activa, tras lc cual se introducirán de nuevo ${ }^{12}$. Abogan por la supresión del tributo no solamente los indios, sino también los mestizos y zambos que temen ser incorporados a los nuevos padrones de tributarios ${ }^{13}$. Quizás un elemento que ofrece, en cierta medida, posibilidades de movilidad social es el botín de guerra, los títulos y promociones militares que reciben los caciques realistas que, de esta manera, afianzarán su posición ${ }^{14}$. Pero estas gratificaciones conciernen fundamentalmente a la élite indígena para reforzar sus lealtades; no se extienden a mestizos y mulatos en general. En todo caso, se crea el precedente de que la guerra puede ser utilizada como medio de ascenso social.

El caso del Alto Perú es distinto. El movimiento se radicaliza, aparecen rasgos de una guerra de castas, emerge un liderazgo indígena y se enfatiza la supresión de repartos, mitas $y$ tributos ${ }^{13}$. Se concede, pues, prioridad al programa indíge-

12 O'Phelan Godoy, Scarlett: La rebelión de Túpac Amaru: Organización interna, Diri. gencia y Alianzas, «Histórica», vol. III, núm. 2, 1979. El artículo de Leon Campbell, publicado posteriormente, en 1981, coincide extensamente con mis planteamientos, aunque sus referencias no sean siempre rigurosas. Social Structure of the Tupac Amaru army in Cuxio, 1780-81, «HAHR», vol. LXI, 4, 1981, págs. 675-693.

13 AGI, Lima, 1.052. Autos seguidos sobre la sedición y tumilto acaecidos en esta ciudad di Arequipa. Año de 1780. Declaración de Juan Josef de Archavala, administrador de correos. «Se les quiere empadronar a los cholos y sambaigos para cobrarles tributos.»

14 Cahill, David: Caciques y Tributos, ponencia presentada al VII Simposio de CLACSO. Lima, 1986. El tema también lo desarrollo en el ensayo «Kurakas sin sucesiones. Del cacique al alcalde de Indios». Informe final sometido a FOMCIENCIAS, Lima, marzo 1989.

15 Hidalgo, Jorge: Amarus y Cataris: aspectos mesiánicos de la rebelión indigena de :781, «Revista Chungará», núm. 10, Arica, 1983. Consúltese también el artículo de Szeminski, Jan: Why Kill the Spaniards? en Steve Stern (ed.): Kesistance, Rebellion and Consciousness', in the Andean Peasant World. Wisconsin, 1987. Una descripción detallada de la rebelión de Túpac Catari aparece en el reciente libro de Valle de Siles, María Eugenia del: Historia de la rebe!ión de Túpac Calari, 1781-1782, La Paz, 1990. 
na, a las demandas indígenas. No obstante, el movimiento está condenado al fracaso - dentro del contexto en que se procuce- debido a que expulsa al componente criollo y entra en contradicción aguda con el componente mestizo. De todos modos hay que reconocer que si en algún momento se propone una inversión de la sociedad colonial es, precisamente, dulante el liderazgo de Túpac Catari, aunque su proyecto resulte impracticable.

\section{Rebeliones como culminación de revueltas menores}

Si bien la correlación entre la presencia de movimientos ce menor alcance y su culminación en una rebelión de carácter más general puede plantearse en el caso del sur andino ${ }^{16}$, esta fórmula no funciona con igual transparencia en el caso de Quito y Nueva Granada.

Efectivamente, en el caso del Perú, numerosos atentados contra corregidores durante la década del 70 y sucesivos ataques a las Aduanas instaladas en el Bajo y el Alto Perú, crearon las condiciones para que cuajara una rebelión de largo aliento como la Tupacamarista ${ }^{17}$. No en vano se incluyeron en el programa las protestas que se habían planteado previamente con insistencia: la supresión de repartos, corregidores, Aduanas y reducción de la alcabala a su tasa original del $2 \%$. A diferencia de Quito y Socorro, en la gran rebelión desde un principio se alude a la erradicación de mitas y tributos, lo

16 O'Phelan, Scarlett: Túpac Amaru y las rebeliones del siglo XVIII, en Flores Galindo, Alberto (ed.): Túpac Amaru II. Antología, Lima, 1976. El argumento es retomado en el libro de Golte, Jurgen: Repartos y Rebeliones, Lima, 1980, aunque su explicación interprete !a presencia de revueltas menores básicamente a partir del reparto de mercanclas del corregidor.

17 O'Phelan Godoy, Scarlett: Hacia una tipologia y un enfoque alternativo de las rebelio. nes y revueltas sociales del Perú Colonial (siglo XVIII), «Jahrbuch für Geschichte von jtaat, Wirtshaft und Gesellschaft Lateinamerikasw, núm. 21, 1984. Ha sido traducido al inglés bajo el título Rebelions in colonial Perú: a Typology of Revolts and the Great Rebellion of 1780, «Annals of Scholarship», vol. 5, núm. 4, 1988.

Tomo XLIX 
cual es índice de la temprana implicación del sector indígeina liderado por sus caciques.

En el caso de Quito, el preámbulo a la rebelión de los barrios no es tan claro. El trabajo de Segundo Moreno Yáñez ${ }^{18}$, al concentrarse en el estudio de las sublevaciones indígenas, no incluye dentro de su análisis la rebelión urbana de 1765. Pero si revisamos la tabla de movimientos sociales que fresenta Moreno en su libro, se constata que no es posible tstablecer una secuencia consistente entre las revueltas que puecedieron a la rebelión de los barrios y el estallido de esta última. No se observa un ciclo preparatorio convulsionado, de gestación, como en el caso del Perú. Si alguna conexión cronclógica se puede inferir es respecto de la sublevación de Riobamba que estalla un año antes, en $1764^{11 "}$.

Pero su naturaleza es completamente diferente. El cle Riobamba es un movimiento indígena contra empadronamientos, tributos y encomiendas, es decir, contra los hacendados. Inclusive, si en algo influyó la experiencia de Riobamba en la rebelión de los barrios, fue en crear temor entre los criollos trente al potencial subversivo de las masas indígenas y, probablemente, en convencerlos de que no debían solicitar la colaboración de provincias del interior tales como Riobamba, Ambato y Latacunga. No en vano se señala que la sublevación de Riobamba, de 1764, fomentó -entre los hacendados criollos - el sentimiento de que los indios podían «matarlos a su arbitrio como incautos y desprevenidos, posesionarse de bienes, haciendas y ganados... contaminando todas las provincias» ${ }^{20}$. En el caso de Quito no es extremo afirmar que las medidas fiscales borbónicas fueron aplicadas prácticamente «en frío», es decir, sin previo aviso. $\mathrm{Y}$ es que, efectivamente, Quito fue la primera ciudad de Sudamérica donde se introdujeron, siendo transferido el control del monopolio de aguarciente y la recolección de alcabalas al Real Erario tan solo en

18 Moreno Yáñez, Segundo: Sublevaciones irdigenas en la Audiencia de Quilo, Bonn, 1')76.

19 Ibidem, págs. 159-162.

20 Archivo Histórico Nacional, Madrid (en adelante, AHN), Consejo, 20.617. 
1764, pocos meses antes que estallara la violencia en Ins barrios. En el caso del Bajo y del Alto Perú, en cambio, 'os insurgentes tuvieron como punto de referencia la experiencia guiteña, por un lado, y supieron canalizar la atmósfera de descontento creada por el escalonado ataque a las Aduanas Jel sur andino, por otro.

Para el caso concreto de Nueva Granada, Anthony McFarjane ha sugerido que, al igual que en el caso del Perú, la rebelión de los Comuneros fue también resultado de una serie de revueltas menores que la antecedieron ${ }^{21}$. No obstante, el bilo conductor no se presenta del todo claro, porque no se articula directamente con las revueltas producto de las reformas, sino que se engarza con protestas de otra índole, como $\mathrm{el}$ ataque al corregidor de Tunja en 1740 y las revueltas anífiscales de 1755, 1756 y 1760 en Ocaña. Incluso el análisis se remonta a la revuelta de los indios de Turmequé, Tunja, que se produjo en $1705^{22}$. La cronología es un tanto ambigıa, las coyunturas imprecisas $y$, por tanto, las conexiones con los Comuneros, poco claras.

Dentro de la línea de argumentación que intenta establecer correlaciones entre las revueltas que precedieron al movimiento Comunero, el reciente trabajo de Gilma Mora de Tovar guarda una secuencia más coherente, en la medida en que $s \in$ concentra en el análisis de las revueltas que estallaron contra la renta y el monopolio del aguardiente ${ }^{29}$. A través de :u

21 McFarlane, Anthony: Civil Disorders and popular protests in late colonial New Granada «HAHR*, núm. 64, 1, 1984, pág. 22. «Indeed, the Comuneros' rebellion may be regarded cs simply the outstanding episode in a pattern of popular action that manifested itself at other times and in other places in eighteenth-century New Granada...»

22 Ibidem, págs. 27, 28, 32.

23 Mora de Tovar, Gilma: Aguardiente y conflictos sociales en la Nueva Granada durante el siglo XVIII, Bogotá, 1988, págs. 175.215. La autora establece una división entre las protestas antes de 1750 , y aquellas que estallaron en la segunda mitad del siglo XVIII. Dentro de estas últimas aborda el tumulto de Tunja de 1752, el de Tuta ocurrido el mismo año, las protestas de los mulatos del Cauca entre 1765-1766, la sublevación de San Francisco de J:ß̧ua en $1774 \mathrm{y}$, finalmente, el movimiento Comunero de 1781. 
estudio se llega a tener una idea más cabal del impacto de las teformas borbónicas que se materializó en el establecimiento de los monopolios, y del malestar que estas medidas crearon e.t los diferentes sectores sociales afectados en tanto su status como productores, comerciantes $\mathrm{u}$ operarios en los centros cit procesamiento y fabricación del licor ${ }^{2-4}$.

No obstante, si bien en el caso de Nueva Granada se puede hablar de antecedentes en la intranquilidad social que precedió a los Comuneros, no se observa una protesta tan reiteraća como en el caso del sur andino, ni una que cubra un radio de acción tan amplio. Las secuencias, por lo tanto, pueden ser similares pero de ninguna manera idénticas; y si algo las distancia del caso del Perú, es la marginalidad que distingue la participación del sector indígena.

\section{Mesianismo y Rebelión}

En el siglo XVIII estallaron numerosas revueltas y rebeliones en el espacio andino; sin embargo, pocas fueron las que presentaron rasgos mesiánicos ${ }^{25}$. Habría que preguntarse por qué. En primer lugar, es difícil encontrar elementos mesiánicos en las revueltas de carácter cotidiano donde no se observa la presencia de una elaboración a nivel ideológico. Los argumentos son de carácter inmediato y difícilmente trascienden este entorno.

24 Kendall Brown realiza un estudio similar para el caso del Perú en su libro Bourbons and Brandy. Imperial Reform in Eighteenth century Arequipa, Albuquerque, 1986.

25 La bibliografía sobre mesianismo y movimientos mesiánicos es extensa. Dentro de los libros clásicos tenemos el de Cohn, Norman: The Pursuit of the Milenium. New York, 1970. Para Cohn las connotaciones de milenarismo y mesianismo son indistintas, ambas son la negación de! orden establecido. Son también bestante conocidos los libros de Lanternari, Vittorio: The Religions of the Opressed, New York, 1963, y el de Adas, Michael: Prophets of Rebellion, Cambridge, 1979. Para el caso del Perú sigue resultando de gran utilidad el libro editado por Juan Ossio: Ideología Mesiánica del mundo Andino, Lima, 1973. Tiene también particular interés el articula de Curatola, Marco: Mito y milenarismo en los Andes: del Taki Onqroy a Inkarri, «Allpanchis Puthuringa», núm. 10, 1977. Para un balance sobre estudios milenaristas consúltese el artículo de Schwart, Hillel: The end of the beginning: Millenarian Studies, 1969.1975, «Religious Studies Review», vol. 2, núm. 3, 1976. 
Es posible, por otra parte, encontrar componentes mesiánicos, sobre todo en los movimientos que alcanzaron connotaciones de rebelión. Esto se debe, en primer lugar, a que la mayor permanencia temporal les brindó la oportunidad de darse a conocer en el plano ideológico. En segundo lugar, el liderazgo de tales movimientos tuvo una composición social mixta: no se advierten sólo elementos criollos, sino también mestizos - caciques y clérigos. Estos estuvieron en capacidad de estructurar un programa que trascendía las puras reivindicaciones económicas y/o las demandas cotidianas. Además, el mesianismo que surgió en los Andes estuvo fundamentalmente ligado a la imagen del Inca. De allí que ejerciera impacto, sobre todo en las masas indígenas ${ }^{26}$. El mesianismo cobró, pues, definición en la gran rebelión que estalló precisamente en el corazón del Imperio Incaico, antes que el caso de la rebelión urbana de Quito, o de la rebelión encabezada por los criollos provincianos y mestizos del Socorro, en Nueva Grarada.

En el caso de Quito, no se advierten referencias al Inca, aunque hay alguna información de que se pensaba coronar, en el momento oportuno, al conde de Selva Florida ${ }^{27}$. El peso de los patricios dentro del movimiento se pone una vez más de manifiesto y debe tenerse en cuenta para cuando se conforma la Junta de gobierno en 1809 . El esquema patricio-plebe que utilizan Phelan y McFarlane para los casos de Nueva Granada y Quito, respectivamente, no se puede aplicar al Perú surandino, donde la presencia de los patricios se diluye frente a la

26 Los artículos de Eugenia del Valle de Siles y Jorge Hidalgo analizan la presencia de elementos mesiánicos en la gran rebelión. El artículo de Leon Campbell incluido en la compi. lación editada por Steve Stern, también guarda un enfoque similar. Valle de Siles, Marla Euge. nis del: Túpac Katari y la rebelión de 1781, «Anuario de Estudios Americanos», vol. XXXIV, 1977, págs. 633-664, y Túpac Katari, el aymara que sitió La Paz, «Actas del Coloquio rúpac Amaru y su tiempow, Lima, 1982. Ilidalgo, Jorge: Amarus y Cataris. Campbell, Leon: Ideology and Factionalism, págs. 110-135.

27 McFarlane: The rebellion of the Barrios, pág. 315. No obstante, para el caso de ia rebelión de Riobamba de 1764, Moreno Yáñez menciona que en el juicio se hace referencia al «Guaminga... que este es un modo inusitado ....on que esta nación aciama a su antiguo Inga...» 
actuación del componente indígena: élite (caciques) y masas (comunidades) ${ }^{28}$.

En el caso de Nueva Granada, la referencia al Inca es más casual que consistente y es, además, inexacta. De acuerdo con el libro de Mario Aguilera Peña, los comuneros de Cocuy y los pueblos llaneros de Támara, Ten y Manare firman, el 23 de mayo de 1781, un comunicado en el que se refieren al rey nuevo de las Indias, el poderoso don José Francisco Túpac Amaru ${ }^{20}$. Las imprecisiones son dos: en primer lugar, en tal fecha Túpac Amaru había sido ya ajusticiado. En segundo lugar, el nombre del cacique era José Gabriel; Francisco era, en todo caso, su tío ${ }^{30}$. Inclusive, entre las añadiduras que se hacen al borrador de las Capitulaciones de Zipaquirá se menciona «Al indio don Josef Gabriel Amaru Tupay quien pretende con toda su alianza despojar a Su Magestad del Reino del Perú, no obstante de habérseles alzado por el señor Virray y Audiencia todos los pechos que motivaron su alzamiento' ${ }^{31}$. Lo que resulta incuestionable es que Túpac Amaru se había convertido en un símbolo de la lucha contra el Mal Gobierno, y que su nombre ejercía gran convocatoria. En los Llanos de Casanare, por ejemplo, Don Javier de Mendoza levantó numerosas poblaciones indígenas presentándose como comisionado de Túpac Amaru ${ }^{2}$. Además, para incentivar el apoyo de los

28 Aunque una excepción podría ser la rebelión de los pasquines de Arequipa, en 1780, también se detecta la presencia del cacique de la Chimba, por ejemplo. Consúltese el libro de Galdós, Guillermo: La Rebelión de los pasquines, Arequipa, 1967. Es también de interés la disertación de Wibel, John Frederick: The Evolution of a Regional Community within Spuntish Empire and Peruvian Nation: Arequipa 1780-1845. Tesis de Ph. D. Universidad de Stanford, 1975.

29 Aguilera Peña: Los Comuneros, pág. 118. John Leddy Phelan también se refiere a la proclama de Silos del 14 de junio de 1781, The People and the King, pág. 108.

30 O'Phelan Godoy, Scarlett: Un siglo de rebeliones anticoloniales, pág. 231. Francisco Túpac Amaru era arriero, casado en Pomacanchis, Quispicanchis. Posela chacras y se desempeñaba también como mayordomo en la hacienda Guallaunco.

31 Friede: Rebelión Comunera de 1781, pág. 98.

32 Pinto Escobar: La Rebelión del Común, pág. 91. Dentro de las manifestaciones de rebeldf́a los indios se negaron a cancelar sus tributos y a asistir a la doctrina. Parece que en las provincias de Pasto y Barbacoas las noticias sobre la gran rebelión crearon, de acuerdo a la autora, una atmósfera propicia para agitar a los pobladores indígenas y a la plebe en general. 
indios de Tequia se difundió el rumor de que «Don José I Túpac Amaro cogió a Lima a fucrza de hambre y armas y aún se dijo que en este Reyno había correspondiencia y apoderados de los rebeldes del Cuzco» ${ }^{33}$.

No obstante, criollos e indígenas asimilarán la figura del Inca de forma disímil. Para los criollos y los caciques prominentes, Inca era la estirpe de la que descendían y que legitimaba sus derechos y su liderazgo. Para las masas indígenas. Inca connotará, en cambio, jefe supremo, redentor. La visión del Inca mesías es la que recrean los indios de comunidad, incentivados por sus dirigentes ${ }^{34}$.

En el caso del Perú, los movimientos que estuvieron en capacidad de desarrollar características mesiánicas fueron el de Juan Santos Atahualpa, en la selva central, y el de Túpac Amaru, en el sur andino ${ }^{35}$. Ambos líderes eran mestizos, bilingües, y habían sido educados por los jesuitas; el segundo era, además, miembro de la élite indígena. De allí sus posibilidades de convertirse en líderes mesiánicos: habían sido adoctrinados con esmero, manejaban el discurso cristiano y las imágenes bíblicas. A pesar de todos estos atributos, habrá quienes se refieran al cacique de Tinta como «adornado de un decernimiento y prendas nada comunes a los yndios, aunque no acierte a explicar todos sus pensamientos por su torpe educación...» ${ }^{33}$. Era obvia la distancia entre ser miembro de la

33 Lucena Salmoral, Manuel: El Memorial de don Salvador Plata. Los Comuneros y los Movimientos Antirreformistas, Bogoth, 1982, págs. 182, 183. Sólo se supo de la derrota de Túpac Amaru después de firmadas las Capitulaciones; sobre todo $n$ n los Llanos se publicaren varios comunicados achacando ser órdenes decretadas por el Inca.

34 Choy, Emilio: Contradicciones y trascendencia de la Revolución, en «Túpac Amaru II. Antología», Lima, 1976, pág. 262. Choy se refierc a la doble personaliciad de Túpac $\Lambda$ m.ıru. He abordado su doble discurso en el estudio Utopía andina, cpara quién? Discursos paralelos a fines de la colonia, ponencia presentada a la Conferencia Anual de la American Historical Association. San Francisco, diciembre 1989.

35 Stéfano Varesse, en su libro La Sal de los Cerros, Lima, 1978, es quien más extensamente ha trabajado los rasgos mesiánicos de Juan Santos Atahualpa. Hay un temprano artículo de Alfred Metraux que también va en esta línea. A Quechua Messiab in Eastern Perú, aAmerican Anthropologist», núm. 44, 1942. Resulta también útil el artículo de Lenartz, Jay: Juan Santos: primitive rebel on the campa frontier (1742-1752) en «XXXIX Congteso Internacional de Americanistas de Lima. Actas y Memorias», vol. 4, Lima, 1972.

36 AGI, Cuzco, 29. Correspondencia oficial remitida al virrey Jáuregui entre 1781-1782. 
élite indígena y pertenecer a la élite criolla y, por lo visto, esta distinción era clara no sólo para peninsulares y criollos, sino también para las masas indígenas.

En las oportunidades en que criollos como Vélez de Córdova, en Oruro, y Farfán de los Godos, en el Cusco, intentaron legitimar sus conexiones incáicas para afianzarse como líderes, fracasaron en su intento, siendo sus conspiraciones abortadas. No les resultó fácil contar con el reconocimiento de los pobladores indígenas, ni asumir el título de Inca-Rey. Además necesitaban siempre recurrir al apoyo de un cacique que actuaba como intermediario entre los líderes criollos y las comunidades. El diálogo con estas últimas no era, pues, directo.

Es posible observar que el curso de los movimientos mesiánicos no coincide necesariamente con el curso de las rebeliones coyunturales. En el caso de Juan Santos, por ejemplo, se trata de un movimiento que estalla en 1742 y permanece en vigencia hasta 1752. Entremedio ocurren —en 1750la conspiración de Lima y la rebelión de Huarochirí, cuyo carácter fue bastante más coyuntural. Quizás ello se deba, como he argumentado antes, a que el movimiento de Juan Santos tuvo un desenvolvimiento paralelo por surgir en un territorio que no había sido incorporado plenamente al sistema colonial y que, por lo tanto, aún no respondía a los ciclos de las rebeliones coyunturales.

\section{La Era de las Insurrecciones Andinas}

Este marco de análisis ha sido propuesto recientemente por Steve Stern, con el propósito de insertar la rebelión de Juan Santos Atahualpa en el contexto de las rebeliones anticoloniales del siglo XVIII ${ }^{37}$. Constituye, además, un intento por demostrar que la sierra central del Perú participó, a su ma-

37 Stern, Steve: The Age of Andean Insurrection, $1742-1782$ en Resistance, Rebellion and Consciousness in the Andean Peasant World, Wisconsin, 1987. 
nera, de la dinámica de lucha social e incluso que Juan Santos fue el eje del cual se nutrieron posteriormente rebeliones como la Tupacamarista.

En un ensayo anterior llamé la atención sobre dos puntos cuestionables en este esquema. En primer lugar establecí que, a mi juicio, el área en la cual se desenvuelve el movimiento de Juan Santos era un territorio que aún se hallaba en la fase de «conversión» y que no había sido incorporado propiamente al sistema de explotación colonial. La rebelión se presenta entonces como una expresión de resistencia ante la posibilidad de ser anexados al engranaje colonial. De allí que no pueda analizarse cabalmente en el mismo nivel de las otras rebeliones genuinamente anti-coloniales ${ }^{38}$.

En segundo lugar argumenté que si había que buscar las raíces del movimiento de Túpac Amaru resultaba más apropiado remontarse a las rebeliones de 1730 , en Cochabamba, y de 1739, en Oruro, antes que a la rebelión de Juan Santos ${ }^{*: 9}$. Cuchabamba y Oruro formaban parte del sur andino al igual que el Cusco y, además, tales provincias no se hallaban en la etapa de «conversión» sino que eran, desde el siglo XVI y el establecimiento del circuito comercial Cusco-Potosí, ejes del s.istema colonial. De allí que sus prog1ámas tuvieran más puntos en común con el de Túpac Amaru, que las coincidencias que se pueden advertir entre éstos y las propuestas agitadas por Juan Santos Atahualpa «a unos indios recién convertidos» que eran, además, el grueso de sus seguidores. La presencia de serranos fue, en todo caso, marginal ${ }^{40}$.

No obstante estas discrepancias, un punto interesante que cmerge del estudio de Stern, es la concepción según la cual la dinámica de lucha social que incluye un proyecto mesiánico so siempre guarda confluencia con coyunturas de intranquilidad social que culminan en rebeliones. El proyecto mesiánico tiene su curso propio durante el siglo XVIII, pero hay puntos de

38 O'Phelan Godoy: Utopía andina ¿para quién? Discursos paralelos a fines de la colonia. (ms).

39 O'Phelan Godoy: Un siglo de rebeliones anticoloniales, capítulo 2, págs. 94-111.

40 O'Phelan Godoy: Utopia andina ¿para quién? Discursos paralelos a fines de la colonia. (ms). 
єncuentro. Es por eso que hay que tomar con cautela la crítica de Leon Campbell en el sentido de que «los eventos de 1780 (la gran rebelión) en vez de ser la lógica culminación de una década de revueltas locales antifiscales, constituiría, mas bien, la culminación de una serie de protestas mesiánicas y nativistas» ${ }^{41}$. Si bien es cierto que el ritmo de los movimientos coyunturales no siempre coincide con el de los movimientos mesiánicos, esto no quiere decir que sean excluyentes. El caso más notable que demuestra que no lo son es, sin lugar a dudas, el de Juan Santos Atahualpa, cuyas protestas aisladas se articulan con el contexto coyuntural en 1750. En la rebelión de Túpac Amaru ambas corrientes confluyen, se anudan y comtinan con éxito la protesta antifiscal y las imágenes mesiánicas. Pienso, sin embargo, que el potencial mesiánico no habría cobrado tal realidad en ausencia del explosivo ingrediente antifiscal.

\section{La tesis de la Utopía Andina}

Otras interpretaciones han tratado de buscar el hilo conductor de las rebeliones anticoloniales en la construcción mental de un proyecto que, reiterativamente, proponía la implan. tación de un nuevo estado, el estado Inca, y la consiguiente erracicación de los españoles. Dentro de este enfoque destacan los recientes trabajos de Alberto Flores Galindo y Manuel Burga ${ }^{42}$.

Vayamos por partes. El panorama de las rebeliones sociales y el estallido de revueltas menores se dio a lo largo del siglo XVIII. No obstante, sólo en contadas ocasiones aparece el discurso que se refiere al retorno del Imperio de los Incas. Concretamente en Oruro (1739), Lima (1750),

41 Campbell, Leon: Ideology and Factionalism during the Great Rebellion, 1780.1782, en Stern, Steve (ed.): Resistance, Rebellion and Consciousness, pág. 115. (la traducción es nuestra).

42 Flores Galindo: Buscando un Inca, Lima, 1986. Burga, Manuel: El nacimiento de la zitopía, Lima, 1988. También puede incluirse dentro de este enfoque el libro de Szeminski, Jan: La Utopia Tupacamarista, Lima, 1983. 
Tarma (1742-1752) y en 'el contexto de la gran rebelión (1780-1782). ¿Por qué?

Los casos que sirven de ilustración permiten postular que el proyecto de la utopía andina no se enarboló en las revueltas menores, ni en las protestaa cotidianas, ni en los enfrentamientos locales. Tal discurso sólo se constata en las conspiraciones y movimientos que alcanzaron connotaciones de rebelión o que encerraban el potencial para convertirse en rebeliones. Me pregunto entonces ¿ por qué el poblador común de las villas, epicentro de las revueltas menores, no enunció este discurso en sus protestas cotidianas?

Regresemos a las rebeliones mencionadas líneas arriba y exploremos la composición social de las mismas. En Oruro ie correspondió al criollo (también descrito como mestizo) Vélez de Córdova - en alianza con el cacique local y varios mestizos artesanos - conspirar y planear la rebelión ${ }^{43}$. En Lima, en 1750, fueron mestizos, indios de la élite y artesanos indíEenas, apoyados por un clérigo franciscano mestizo, los que proyectaron alzarse ${ }^{44}$. En Cusco la Conspiración de Plateros de 1780 fue convocada por un criollo, Farfán de los Godos, quien incluyó en sus proyectos al cacique Pisac y varios artesanos criollos y mestizos ${ }^{45}$. La rebelión de Túpac. Amaru es bastante conocida: su programa acogió a todos los sectores sociales lesionados por la política borbónica. Dentro de ellos, criollos y mestizos llevaron la voz cantante, sobre todo durante la primera fase del movimiento.

En este sentido quisiera cuestionar, una vez más, la aseveración de que la utopía andina fue concebida por el pobla-

\footnotetext{
43 Lewin, Boleslao: La Rebelión de Túpac Amaru y los origenes de la Independencia de Hispanoamérica, Buenos Aires, 1957, págs. 118-119. Consúltese también mi libro Un siglo de Rebeliones Anticoloniales, págs. 104-106.

44 Spalding, Karen: Huarocbiri: An Andean society under Inca and Spanish Rule, Stanford, 1984, capítulo 9, The Challenge to Colonialism. Consúltese también mi libro, Un siglo de Rebeliones Anticoloniales, págs. 111-116.

45 Angles Vargas, VIctor: El cacique Tambobuacso, Lima, 1975. Consúltese también mi libro, Un siglo de Rebeliones Anticoloniales, págs 207-217.
} 
dor indígena y de allí irradió a otros sectores sociales ${ }^{46}$. Está claro que estas formulaciones no aparecen en las revueltas sino $\in \mathrm{n}$ las rebeliones, donde la dirigencia es étnicamente mixta. Pienso que criollos y clérigos tuvieron más injerencia en la difusión del discurso del retorno de los Incas de lo que, hasta el momento, se les ha atribuido.

En un trabajo anterior planteé que el colegio de San Borja, en el Cusco, fue indudablemente un foco importante para propagar esta tesis ${ }^{47}$. No sólo porque en él confluían para recibir la formación que impartían los jesuitas, los criollos provincianos y desde luego, los caciques del sur andino, sino además porque el sur andino había constituido el eje del Imperio Incaico. De allí que caciques y criollos se sintieran descendientes directos de los Incas. Este era un elemento que no se daba con igual fuerza en el caso de Nueva Granada o Quito donde, " mediados del siglo XVIII, la élite indígena estaba ya en franco proceso de descomposición, mostrando fisuras en el sistema de sucesión y de representatividad comunal.

En la rebelión de Riobamba - que antecede a la quiteña de 1765 - se acusó a los caciques de Yaruquíes y Punín de haber alentado las confrontaciones, aunque no se reunieron pruebas fehacientes que permitieran condenarlos. Sí hay alguna participación más clara, ésta es la del cacique de Licán quien, paradójicamente, se pone de parte de las autoridades españoias ${ }^{48}$. Durante la rebelión Comunera, por otro lado, Ambrosio Pisco se encargó de organizar el apoyo de las masas indígenas en consideración a que su abuelo, Don Luis, había sido

\footnotetext{
46 Flores Galindo: Buscando un Inca, pág. 65. Mis discrepancias con esta afirmación las he planteado en el ensayo Utopia Andina ¿para quién? (ms.).

47 O'Phelan Godoy: Utopia Andina ¿para quién? (ms.); para información sobre el Colegio jesuita San Borja del Cusco me remito al trabajo de Pablo Macera La Enseñanza elemestal en el coloniaje, «Trabajos de Historia», tomo II, Lima, 1977, y al libro de Gisbert, Terisa: Iconografia y Mitos indigenas en el Arte, La Paz, 1980.

48 Moreno Yáñez: Sublevaciones Indígenas, pág. 83. La información sobre el envolvimiento de los caciques es velada, se especula sobre el contacto entablado por dos caciques de Riobamía en la ciudad de Quito, y se trata de inculpar a Justo Tigsilema y Pablo Sañay, caciques de Yaruquíes y Punín, respectivamente. Se alude a que Tigsilema temía ser depuesto de su calyo por su comprobada embriaguez y maltrato a los indios.
} 
el último cacique de Bogotá ${ }^{+9}$. Poco antes de estallar la rebelión, Pisco había solicitado oficialmente que se le adjudicara c.! título aduciendo que era tío directo del legítimo heredero quien, a la sazón, era menor de edad ${ }^{50}$. No obstante, para 1781, el cacicazgo se había reducido a unas cuantas villas esparcidas y a Pisco lo conocían más como comerciante, que como ciescendiente de caciques.

Algo muy distinto a lo que ocurrió con Túpac Amaru, quien combinaba con éxito estas dos actividades. Para los criollos y mestizos del sur andino, era el diligente arriero que transjortaba productos entre el Bajo y el Alto Perú. Para los indígenas era el afamado cacique que había ido a Lima a solicitar que los indios de Tinta y las provincias aledañas dejaran de mitar en Potosí ya que, desde 1776, las minas potosinas - como el resto del Alto Perú- habían sido transferidas al Virreinato de Buenos Aires. Además, su largo litigio para acreditar ser legítimo descendiente del Inca Túpac Amaru I le había hecho bastante conocido entre los pobladores del rur andino ${ }^{51}$.

Así como en México la religión fue el elemento que aglutinó a criollos, mestizos e indígenas bajo el manto de la Virgen de Guadalupe, punto de encuentro de los diferentes sectores sociales $^{52}$, en el caso del Perú fue el Inca la figura a la que recurrieron criollos provincianos y caciques mestizos para garantizarse el apoyo de las masas indígenas. La presencia de una élite indígena aún significativa que, además de reproducir sus relaciones con las comunidades a través de los tributos y la

49 Phelan: The People and the King, pág. 101.

50 Pinto Escobar: La Rebelión del Común, pág. 83. Ambrosio Pisco tumbién solicitó se le extendiese su jurisdicción sobre los indios de Santa Fe, Tunja, Vélez y Sogamoso. La R.cial Audiencia no llegó a dar un fallo debido a que estalló la rebelión de Socorro.

51 Rowe, John: Genealogia y Rebelión en el siglo XVIII: antecedentes de la sublava. ción de José Gabriel Thopa Amaro, «Histórica», vol. 6, núm. 1, 1980.

52 Para este tema resulta de gran interés el libro de Jacques Lafaye: Quetzalcóall and Guadalupe. The Formation of Mexican National Consciousness 1531-1813, Chicago, 1987. También es de utilidad el artIculo de William Taylor: The Virgin of Guadulupe in New Spain: an inquiry into the social bistory of Marian devotion «American Ethnologist», núm. 8, 1981. 


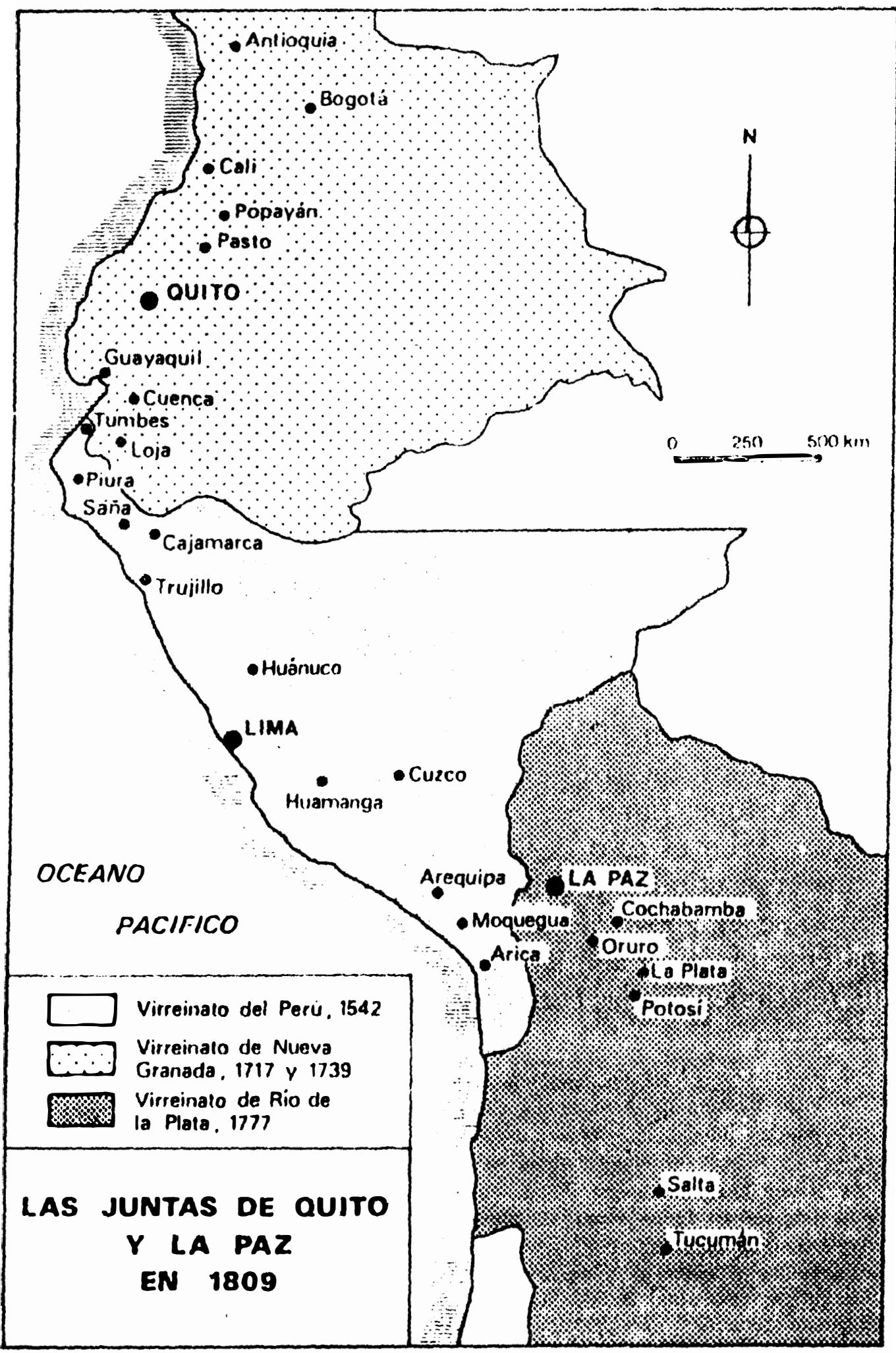


mita de Potosí, se preciaba de su estirpe Inca, permitió gestionar la colaboración de las comunidades del sur andino ${ }^{53}$.

Segunda Parte.

El Análisis Comparativo

\section{Indios y Caciques}

Si comparamos las rebeliones de Quito, Nueva Granada y el Perú, se pone de inmediato en evidencia que en Quito y en Socorro la población indígena no era mayoritaria. Los centros urbanos coloniales solían albergar a la población blanca, sus esclavos de servicio y una porción de indígenas que, habiendo abandonado sus comunidades de origen, se desempeñaban como artesanos y pequeños comerciantes ${ }^{n-1}$. Los caciques, en este contexto, no tenían razón de ser.

Uno de estos casos es el de Socorro, donde la población era fundamentalmente blanca y mestiza. De acuerdo al censo de 1778, en el Virreinato de Nueva Granada sólo el $15 \%$ de sus habitantes eran indios. En la provincia de Socorro, el censo registró la presencia de 712 nobles, 2.924 blancos, 4.175 mestizos, 1.169 mulatos y sólo 110 indios ${ }^{55}$. Ello implica que la influencia que la élite indígena podía lograr era bastante limitada. No hay que olvidar que la rebelión de los Comuneros sólo fue captando la adhesión de los pobladores indígenas cuando avanzó hacia Bogotá. No nació como un movimiento en el que destacara un significativo contingente indio. Una vez más, los caciques poco tenían que hacer en una rebelión de esta naturaleza y, además, el extenso mestizaje anulaba la posibilidad de que en Nueva Granada el sistema

53 O'Phelan Godoy: Un siglo de Rebeliones Anticoloniales, pág. 231.

54 Andrien: Economic crisis, taxes and the Quito Insurrection of 1765, págs. 117-118. Es interesante el enfoque que ofrece el autor sobre la población marginal de los barrios quiteños de San Roque, San Sebastián, San Marcos y Santa Prisca.

55 Aguilera Peña: Los Comuneros, pág. 58. 
cacical se reprodujera o ejerciera una influencia decisiva. Una єxcepción, fue, claro, el caso de Ambrosio Pisco, quien poco artes de la rebelión Comunera reclamó jurisdicción sobre los indios de Santa Fe ,Tunja, Vélez y Sogamoso.

En el caso del Perú, la gran rebelión estalló en el sur ancino, donde se concentraba la población indígena del Virreinato -alrededor del $70 \%$ - y donde, por lo tanto, los caciques cumplían un papel vital ${ }^{56}$. Siendo líderes comunales pasaron a convertirse en líderes de la rebelión. Sus lazos con los pobladores indígenas eran fuertes y no se reproducían básicamente a través de las fiestas de las cofradías - como ocurría en el caso de México, donde cobró importancia notable la Iglesia ${ }^{57}$. Dependían aún de mecanismos tradicionales que congregaban a las comunidades tales como eran la recolección del tributo y la mita de Potosí. Como he señalado en otro trabajo, la mita demostró que los caciques que enviaban anualmente una cuota de mitayos a Potosí estuvieron en óptimas condiciones para remitir refuerzos durante la gran rebelión ${ }^{5 x}$. Tenían poder de convocatoria y mando sobre los indios de su comunidad. La mita articulaba, además, dieciséis provincias del sur andino que reprodujeron esta red de contacto durante la rebelión Tupacamarista. No hubo dudas ni improvisación por parte de los caciques, que utilizaron mecanismos y estructuras que estaban en plena vigencia.

\section{Minas y Arrieraje}

Otro importante elemento cohesionador que estuvo totalmente ausente en el caso de Quito fue la presencia de un

56 Memoria del Virrey Amat y Junient. British Museum (Londres) Additional (ms.) 19, 573. El Arzobispado de Chuquisaca, y los Obispados de Cuzco, La Paz y Misque sumaban 254.467 indios varones en 1774. Le segulan en densidad Lima con 51.240 y Trujillo con 43.380.

57 Farris, Nancy: Maya Society under colonial rule, Princeton, 1984. El artículo de Gruzinski, Serge: La segunda aculturación: El estado ilustrado y la religiosidad indigena en Nueva España (1775-1800), «Estudios de Historia Novoh:spana», vol. VIII, México, 1985, también resulta de gran utilidad.

58 O'Phelan Godoy: Las comunidades campesinas y las rebeliones del siglo XVIII, "Co.munidades Campesinas. Cambios y Permanencias», Lima, 1986, pág. 99. 
circuito comercial minero lo suficientemente consolidado como el montado alrededor de las minas de Potosí. El radio de expansión de la gran rebelión coincide, prácticamente se superpone, al circuito de Cusco a Potosí ${ }^{59}$. La intranquilidad social también se apodera de las minas de Oruro, en 1781, y durante la segunda fase de la gran rebelión los indios mitayos de Potosí solicitaron «exaltar el levantamiento en esos lugares»"

Quito, al carecer de un complejo minero similar, perdió las posibilidades de utilizar este tipo de redes para expandir an rrovimiento social. Las minas de Zaruma tuvieron una explotación espasmódica sin llegar a descollar. Por otro lado, el tráfico comercial quiteño de consideración, más que llevarse a cabo por tierra, se hacía a través de! puerto de Guayaquil ${ }^{\text {*1 }}$. Pienso que el fenómeno de fragmentación de las comunidades indígenas que advierte Moreño Yáñez, bien pudo haberse debido a la ausencia de un eje articulador semejante al Potosí altoperuano. Esto repercutió en que el comercio interno se compusiera de rutas fragmentadas. Además, durante el siglo XVIII estalló en la Audiencia de Quito una secuela de epidemias que diezmaron a la población indígena. Esto debió agudizar aún más la dislocación o aislamiento de sus comunidades, que vieron reducirse el elemento humano con el cual podían contar para reproducir sus redes de contacto regional. La situación «intermedia» de la Audiencia, entre los virreinatos de Nueva Granada, en el norte, y del Perú, en el sur, la hacía aún más vulnerable a la propagación de las pestes que la atacaban por dos flancos. Así, en la década del 40 y del 50, la

59 Mörner, Magnus: La rebelión de Túpac Amaru en el Cuzco desde una perspectiva nueva, París, 1976. Flores Galindo establece la misma analogía en su artículo Túpac Amaru y la st:blevación de 1780, en «Túpac Amaru II. Antología», Lima, 1976.

60 AGI, Buenos Aires, 319. Proceso judicial de Miguel Bastidas. Para la rebelión de Oruro consúltese el articulo de Cajlas, Fernando: Los objetivos de la revolución indizena de 1781: el caso de Oruro, «Revista Andina», vol. I, núm. 2, 1983.

61 Hamerly, Michael: Historia social y económica de la antigua provincia de Guayaquil. 1763-1842, Guayaquil, 1973. Es también de grin utilidad el reciente libro de Laviana Cuetos, Marla Luisa: Guayaquil en el siglo XVIII. Recursos Naturales y Desarrollo Económico, Serilla, 1987. Guayaquil era considerado el puerto ixportador por excelencia. Corsúltese también Miño Grijalva, Manuel (ed.): La Economia Social. Relaciones socio-económicas de la Réal Audiencia de Quito, Quito, 1984. Es de particular interés el estudio introductorio. 
Audiencia quiteña sufrió el impacto de la epidemia de viruelas que se originó en Lima y, en 1760, la gripe asiática la alcanzó desde Bogotá. Entre 1763 y 1764, numerosos indios habían sucumbido en Quito y sus alrededores, precisamente en los años previos a la rebelión de los barrios ${ }^{82}$.

En el caso de Nueva Granada, la expansión del movimiento de Socorro hacia Bogotá cubrió de alguna manera la ruta Socorro-Popayán, en la cual Santa Fe de Bogotá era un punto intermedio. Además, llegaron ecos del movimiento Comunero a centros mineros tales como Rionegro, Guarne y Palencia que se aunaron a solicitar la abolición de impuestos, la extinción de pulperías y rebajas en dos de los productos estancados: tabaco y aguardiente ${ }^{\text {b3 }}$. Es preciso recordar que Zipaquirá era también conocida por sus minas de sal gema explotadas por los indígenas, las cuales pasaron a manos de un administrador especial en 1777 , suscitándose serias protestas ${ }^{64}$. Si bien es posible que estos circuitos comerciales no estuvieran tan bien integrados o arraigados como el de Potosí, fueron aprovechados de un modo similar para los propósitos de propagación del movimiento Comunero. Es mas, en este sentido, Ambrosio Pisco debió jugar un papel clave. Pisco, además de ser propietario de mulas, se desempeñaba como administrador de los monopolios de aguardiente y tabaco. Al igual que otros hacendados y comerciantes de la localidad, mantenía tiendas en Bogotá, a las que abastecía periódicamente ${ }^{\infty}$. Las rutas comerciales le re-

62 Browne, Suzanne A.: The Effects of Epidemic Disease in Colonial Ecuador. Tesis de Ph. D. Duke University, 1984, págs. 134, 135. Aparte de las epidenias mencionadas hubo también algunas enfermedades endémicas como el tabardillo, catarros y fiebres.

63 Aguilera Peña: Los Comuneros, pás. 159. Fue recién en el siglo XVIII cuando las minas de Rionegro se convirtieron en el nervio de la producción de oro antioçueño. Pura detalles al respecto consúltese el libro de Twinam, Ann: Miners, Merchants and Furmers in colonial Colombia, Texas, 1982, pág. 37. No obstante, si bien a mediados del siglo XVIII la minería antioqueña producía el doble que a comienzos de siglo, su producción aún era menor que la de la provincia de Popayán, la cual abarcaba al Chocó y al actual Nariño.

64 Cárdenas Acosta, Pablo E.: Del Vasallaje a la Insurrección de los Comuneros, Tunja, 1947, cap. X, págs. 337, 338. De acuerdo a Pinto Escobar: La Rebelión del Comun, pág. 83, el líder Ambrosio Pisco ofreció a los indios cie Nemocón restituirles las salinas que ellos hablan usufructuado desde tiempo inmemorial.

65 Phelan: The People and the King, pag. 100. 
sultaban conocidas y los contactos con la ciudad estaban convenientemente tendidos. De esta manera los ircuitos del aguardiente y el tabaco también contribuyeron a facilitar el avance del ejército Comunero hacia la capital.

En efecto, otro elemento que confirma la importancia de las rutas comerciales en la difusión de la rebelión de los Comuneros y de la gran rebelión puede verse en la comprobada participación de arrieros en ambas insurrecciones, Aguilera Peña, en su libro sobre los Comuneros del Socorro, presenta cuadros donde aparecen varios arrieros que fueron procesados por sus conexiones con la rebelión además, claro está, de Ambrosio Pisco ${ }^{\not 6}$. En el caso del Bajo y el Alto Perú, este fenómeno fue aún más evidente, en la medida que el clan Túpac Amaru manejaba una próspera empresa de arrieraje que prestaba servicios, precisamente, en la ruta Lima-Cusco-Potosí. Adicionalmente, los libros de la Aduana del Cusco demuestran que Túpac Amaru y sus parientes transitaron activamente a ic largo de esta ruta en los meses previos al estallido de la gran rebelión ${ }^{67}$. No en vano estuvieron en condıciones de usegurarse el apoyo de los gremios de arrieros, trajinantes y viajantes del sur andino ${ }^{68}$.

Lo que sí es obvio, es la dificultad que experimentó un movimiento urbano (como el de Quito) para expandirse a las provincias del interior $y$, a su vez, las limitaciones de las rebeliones que estallaron en las provincias (como Socorro y Tinta), para poder tomar con éxito las ciudades. Como si la contradicción ciudad-campo fuera imposible de superar. En el caso del movimiento de Socorro, se llegó a cercar la ciudad de Bogotá lo cual, indudablemente, supuso un factor de presión durante las negociaciones de Zipaquirá ${ }^{80}$. En cuanto a Túpac Amaru, se le increpó por no haber aprovechado estratégicamente el

66 Aguilera Peña: Los Comuneros, pág. 145.

67 O'Phelan Godoy, Scarlett: Aduanas, mercado interiso y élite cumercial en el Cusco antes $y$ después de la gran rebelíb́n de 1780, AApuntes», núm. 19, 1986, pág. 61.

68 O'Phelan Godoy: Un siglo de Rebeliones Anticoloniales, pág. 233.

69 Phelan: The People and the King, capitulo 16. 
desconcierto inicial que provocó su rebelión para capturar el Cusco ${ }^{70}$. El cacique optó más bien por avanzar hacia el Alto Perú, ruta que conocía, y donde, además de sus redes de arrieiaje, también tenía establecidos lazos de parentesco.

\section{Parentesco y Caudillismo}

En el siglo XVIII las redes del parentesco sobresalen como un núcleo cohesionador de importancia, frente a la inminente ausencia de partidos políticos constituidos. No obstante, el s.jgnificado del alcance del sistema de parentesco no será uniforme. En el caso de Socorro, los cuadros de Aguilera Peña demuestran los vínculos entre parientes a nivel de lo que él domina «capitanes acaudalados» y también a nivel de la oficialidad del ejército comunero. Allí traban lazos tíos, primos, sobrinos, cuñados ${ }^{71}$. El trabajo prosopográfico que realiza Phelan con relación a los lazos establecidos entre las familias $\mathrm{Ar}$ dila, Berbeo y Estévez, ofrece una idea clara del entramado sobre el cuál construyó sus contactos la élite socorrana ${ }^{72}$. Lo mismo se advierte, de alguna manera, entre la élite quiteña: Francisco de Borja, uno de los incitadores de la convocatoria a Cabildo Abierto en 1765, tramitará el respaldo de los más ilustres vecinos de la ciudad, valiéndose de sus vínculos de parentesco. Esto no le resultó difícil en la medida de que su suegro, el alférez real Juan de Chiriboga, era uno de los productores de azúcar más importantes, insumo del cual se obtenía el «aguardiente de caña» ${ }^{73}$.

Pero, en el caso del sur andino peruano el entretejido es más complejo, en la medida que se extiende a lo ancho de comunidades enteras que se sustentan en sus ayllus o unida-

70 Choy: Contradicciones y trascendencia, pág. 261. «La revolución de Túpac Amaru una lez que llegó frente al Cuzco se caracterizó por su autodefensa. En véz de continuar avanzando y tcmar la ciudad, se limitó a sitiarlaw.

71 Aguilera Peña: Los Comuneros, pág. 104.

72 Phelan: The People and the King, pág. 64.

73 McFarlane: The Rebellion of the Barrios, págs. 288, 289. 
des familiares de referencia. Un cacique como Túpac Amaru ro controlaba sólo a sus parientes cercanos, sino también a las comunidades de Pampamarca, Surimana y Tungasuca, todas contenidas en su cacicazgo. De los ayllus que conformaban estas comunidades se nutrieron sus cuadros militares. Los lazos de parentesco adquieren, entonces, una dimensión bastante diferente de la que se presenta en Quito y el Socorro a nivel de la élite criolla. La adhesión de comunidades indígenas puede llegar a tener una configuración masiva.

En su defecto es probable que en Quito y Socorro los gremios y cofradías hayan jugado un papel más decisivo en la conformación de los cuadros ${ }^{74}$. En ambas insurrecciones es posible detectar el envolvimiento de artesanos, sin que esto signifique que se haya constatado su vinculación con determinadas cofradías o hermandades.

Pero el parentesco será un arma de doble filo. Por un lado, en el caso de la rebelión de Huarochirí de 1750, no sólo el clan Puipulibia recurrirá a los lazos familiares para forjar el alzamiento. El militar encargado de reprimir la insurrección, Francisco de Melo, se apoyará también en los numerosos compadres que tenía en diversos pueblos huarochiríes para reclamar sus lealtades y sofocar la rebelión ${ }^{75}$. Como él mismo explicará en su Diario Histórico «tenía yo en el pueblo de la Asupción, en aquel tiempo, sobre treinta compadres» ${ }^{76}$. Las redes de parentesco no sólo abarcarán la consanguinidad sino también las alianzas de padrinazgo que forjaron los españoles a través de ritos cristianos como el bautizo y el matrimonio.

Por otro lado, la relevancia que cobró el parentesco acarreará sus propias contradicciones, sus propias trampas. Las

74 Ibídem, pág. 293. En el caso de la rebclión de Socorro se establece la presencia de ocho artesanos, entre los capitanes y activistas. Consúltese Aguilera Peña: Los Comuneros, pág. 6.

75 Museo Mitre (Buenos Aires), Ms. ArmB, C19, 1, núm. de orden 4. Diario Histórico del Levantamiento de la provincia de Huarochiri, fols. 18, 19. Fue también su comadre, María Rosa, esposa del indio Pedro Chicote, quien lo enteró del alzamiento del pueblo de la Asunción, diciéndole «compadre, vengo a toda prisa a avisarte como mi pueblo, desde ayer domingo ror la mañana, está en armas y puesto en cuartel con todos los catorce pueblos del repartimiento de Challaw.

76 Ibídem, fol. 19 
iealtades entre parientes llevarán a que, en más de una ocasión, los líderes rebeldes sean denunciados y traicionados por su propio círculo familiar, puesto que éstos estaban enterados del paradero de los insurrectos. No es casual que en la conspiración de Plateros del Cusco, de 1780, el cacique Tambohuacso fuese delatado por su cuñado a quien, en reconocimiento, se le adjudicó el cacicazgo ${ }^{77}$. En forma similar, el líder aymara Túpac Catari fue también entregado por Tomás Sisa López, pariente cercano de su esposa ${ }^{78}$. Las redes de parentesco fueron utilizadas tanto para organizar, como para desmantelar los movimientos sociales.

Los hacendados de Socorro y la élite de Quito (constituida ésta última en gran medida por hacendados «ausentes» con propiedades en Ibarra, Latacunga, Riobamba, Ambato) ${ }^{79}$, tenđrán que buscar otros mecanismos para reclutar sus tropas. Los capitanes comuneros propietarios de haciendas, estancias, potreros y sobras de resguardo ${ }^{80}$, tendrán que establecer sus propios códigos y lealtades. Pienso que es en este momento cuando comienza a operar, incipientemente, el caudillismo provincial. Debido a su status de hacendados y no de caciques, estos líderes forjarán la relación patrón-cliente, que aparecerá con más nitidez en el temprano siglo XIX. Con el énfasis çue las Reformas Borbónicas pusieran en la revitalización de la producción agrícola ${ }^{81}$, la hacienda recobrará su importancia no sólo como unidad económica sino también como entidad polí-

77 Angles Vargas, Vlctor: El cacique Tambobuacso.

78 Valencia Vega, Alipio: Julidn Tupaj Katari, Buenos Aires, 1950, pág. 197. El nombre de brtalla de Tomás Sisa era Tomás Inca Lipe, y se afirma que era hermano de Bartolina Sisa, esposa de Túpac Catari.

79 Fernández Martínez, Montserrat: La alcabala en la Audiencia de Quito. 1765.1810. Cuenca, 1984. En el cuadro núm. 40 de la pág. 144 aparece una lista de los ducños de propiedades agropecuarias, muchos de los cuales eran vecinos de Quito.

80 Afuilar Peña: Los Comuneros, páss. 40, 41 y 54. Berbeo, por ejemplo, era un hacendado con varias propiedades y numerosos eaclavos. Salvador Plata combinaba todo tipo de actividades económicas, como era el caso de los miembros de la élite colonial. Era comerciante, hacendado, rentista, contando con propiedades y esclavos.

81 Halperin Donghi, Tulio: Reforma y disolución de los Imperios Ibéricos, 1750.1850, Madrid, 1985, pág. 51. 
tica. Bajo estas condiciones, el caudillismo encontrará el terreno adecuado para florecer ${ }^{\mathrm{s} 2}$.

A ello contribuirá también el hecho de que, para fines del siglo XVIII, el sistema cacical estaba en estado de crisis. Es más, luego de la gran rebelión y tras descubrirse el potencial político de los caciques, se tomarán medidas correctivas que implicarán decretar la abolición de las sucesiones cacicales ${ }^{83}$. Aparecerá entonces una nueva estirpe de caciques, de origen criollo, que contribuirá al deterioro irreversible de las relaciones de reciprocidad andina ${ }^{84}$. Esta nueva casta de caciques-hacendados fortalecerá las relaciones en cuyo marco ya se movían muchos terratenientes criollos y peninsulares, las relaciones patrón-cliente, propias del contexto agrario y base del emergente caudillismo. Abolir los cacicazgos supuso, de alguna manera, dejarles el campo libre a los caudillos locales y proporcionarles un acceso más directo a las comunidades.

\section{Violencia cotidiana y guerra de castas}

Los trabajos de Ward Stavig — para el caso del Cuscohan resaltado la importancia de la vida cotidiana para explicar enfrentamientos que se suscitan durante revueltas y rebeliones ${ }^{85}$. Es indudable que durante períodos de agitación social emergen $e$, inclusive se intensifican, contradicciones que se ha-

82 Sobre el fenómeno del caudillismo existe una bibliografla extensa. No obstante, resiltan de gran interts dos ensayos de John Lynch, sobre el tema: Los caudillos de la Independenia: Finemigos y agentes del Estado-Nación y El gendarme necesario: Ell caudillo como agente del olden social, 1820-1850. Ambos se hayan incluidos en su libro Hispanocmérica 1750-1850. Ensayos sobre la sociedad y el Estado, Bogoth, 1989.

83 Dlaz Rementería, Carlos: El cacique en ei Virreinato de Perú, Sevilla, 1978, pág. 50.

84 Cahill, David: Caciques y tributos, ponencia presentada al VII Simposio de CLACsO, Lima, 1986. La tesis de Licenciatura de Nuria Sala y Vila trae también información relevante. Alborotos, alzamientos, inquietudes, tolle-tolles en el espacio peruano (1782-1808). Universidad de Barcelona, 1985, pág. 183.

85 Stavig, Ward: Violencia cotidiana de los naturales de Quispicanchis y Canas y Canchis en el siglo XVIII. «Revista Andinaw núm. 3, 2, 1986. También resulta de interé su articulo Ethric conflict, moral economy and population in rural Cusco on the Eve of the Thupa Amaro II Rebellion, «HAHR*, núm. 68, 4, 1988. 
llaban latentes en la sociedad colonial. Se ataca selectivamente a un clérigo que había expropiado tierras de comunidad; se pasa de un asalto a la Aduana hacia la violencia contra el corregidor y sus repartos; las comunidades enemistadas por litigios de tierras se enfrentan militarmente; se recrudecen los conflictos interétnicos; caciques advenedizos son heridos o muertos ${ }^{86}$. Las rebeliones simulan un laboratorio en el que se manifiestan las tensiones irresueltas. Se convierten en el terreno donde se saldan cuentas pendientes, sobre todo si no ha habido mecanismos catalizadores, válvulas de escape.

De allí que en algunas ocasiones se conviertan en guerras de castas, propiciando la polarización que ubica al sector blanco a un extremo y a la población india al otro. En el caso del Socorro la oposición no es tan tajante. Sólo surge en el caso de la jurisdicción de Honda, ámbito en que se registra la consigna «mueran los blancos» ${ }^{87}$. Los antagonismos no son tan pronunciados debido, probablemente, a que el líder mulato - o mestizo- José Antonio Galán y el dirigente de las masas indígenas, Ambrosio Pisco, podrán insertar sus demandas en las Capitulaciones de Zipaquirá, aunque después sean condenados a muerte y exilio, respectivamente, mientras que se nombra corregidor de Socorro al líder criollo, Juan Francisco Berbeo ${ }^{88}$.

En el caso de Quito, el inesperado ataque indígena de la noche de San Juan dejará huella en la élite criolla como indudablemente dejarán marca los 109 días que el líder aymara Túpac Catari mantuvo sitiada la ciudad de La Paz ${ }^{89}$. Es, precisamente, a partir del 24 de junio de 1765 , día de San Juan,

86 O'Phelan Godoy: Un siglo de Rebeliones Anticoloniales, págs. 160, 204, 236, 237.

87 Aguilera Peña: Los Comuneros, pág. 133.

88 Phelan: The People and the King, pargs. 190, 219, 226, 240.

89 McFarlane: The Rebellion of the Barrios, págs. 310-313. El autor describe los eventos ccmo un violento alzamiento anti-europeo y contra el gobierno nacido en los barrios y que refleja la animadversión de los pobres contra los ricos. Sobre el cerco de La Paz es de indispensable lectura el libro de Valle de Siles, María Eugenia del: Testimonios del cerco de La Paz, La l'az, 1980. Información de un testigo de los acontecimientos es la que aparece en el Diario del Cerco de La Paz, recapitulado por el oidor Francisco Tadeo Díez de Medina, publicado en La Paz en 1981, con introducción yn estudio a cargo de Marla Eugenia del Valle de Siles. 
cuando McFarlane establece el tránsito de revuclta a rebelión en el caso de la insurrección de los barrios quiteños. La convulsión social se extiende entonces de los barrios de San Roque y San Sebastián y una manifestación contra el corregidor se transforma en un movimiento anti-europeo al que se aunan los pobladores indígenas de las villas aledañas ${ }^{*}$. La «invasión indígena» será la pesadilla que se apodere de peninsulares y criollos en Quito, así como el hambre, la epidemia y la muerte debidas al cerco aymara, quedarán grabados en la memoria de los vecinos de $\mathrm{La} \mathrm{Paz}$. Un testigo de los hechos, el oidor de la Audiencia de Charcas, Francisco Tadeo Díez de Medina, dejará registrado en su Diario, el día 14 de abril de 1781 «...el bloqueo en que nos tienen los indios, sitiados no sólo por víveres que no internan a la ciudad... sino por la falta de agua y fuentes que no corren, por haber cortado los enemigos, desde el principio del sitio, las cañerías o acueductos de la ciudad» ${ }^{91}$. En otro acápite se referirá a «la grita y algazara de los indios con todos aquellos improperios, injurias, desvergüenzas y osadía contra los españoles, que llaman káras, que antes de esta sedición ni se vieron ni oyeron» ${ }^{\boldsymbol{} 2}$.

El temor subyacente a una guerra de castas se pondrá de manifiesto en 1809, cuando tanto Quito como La Paz tengan iesquemor de incorporar a la población india en las platatormas políticas de las juntas de gobierno ${ }^{93}$. Y es que, a diferencia de Nueva Granada, en Quito y más aún en el Alto Perú, ‘a población indígena era masiva. En Quito, a fines del siglo XVIII, alrededor del $60 \%$ de los habitantes eran indígenas;

90 McFarlane: The Rebellion of the Burrios, pág. 310-313

91 Díez de Medina: Diario del Cerco ue la Paz, 1781, príg. 131. Dos semanas después, el 1 de Mayo, anotará «Que siendo mayor el número de los sitiados y con más armas, instrucción y honor que el de los bloqueadores y estos bárbaros (los indios) nos tengan a raya, así oprimidos dentro del piso y terreno de seis a siete cuadras en círculo, sin disposición ni esplritu para rebatirlos, castigarlos y proveer la ciudad de carnes y comestibles».

92 Díez de Medina: Diario del Cerco de La Paz, páz 141.

93 O'Phelan Godoy: Por el Rey, Religión y la Pallia. Las junlas de gobierno de 1909 en La Paz y Quito, «Boletín del Instituto Fiancés de Estudios Andinos», núm. XVII, 2, 1988, pág. 77. 
en la Intendencia de $\mathrm{La} \mathrm{Paz}$ el $99,3 \%$ eran indios ${ }^{94}$. Los criollos aprendieron de la gran rebelión que, en lo sucesivo, las insurrecciones no podían escapárseles de las manos, que no podían exponerse a la irrupción de las masas indígenas. Esto sólo era posible asumiendo el liderazgo y control de los movimientos sociales. El siglo XIX les brindará las condiciones para colmar sus aspiraciones de autonomía sin tener que :ncurrir en flagrantes contradicciones para justificar su actuación folítica.

Tercera Parte. Una vieja discusión.

REBEliones ANDINAS

Y GuERRAS DE INDEPENDENCIA

El bilo conductor: las Reformas irresueltas

Creo que si se trata de buscar un hilo conductor, un puente que conecte las rebeliones del siglo XVIII con las juntas de gobierno del temprano XIX en los Andes, se hace necesario indagar en la naturaleza y puesta en práctica de las Reformas Borbónicas. Cada vez resulta más evidente constatar que la brecha que abrieron las reformas entre España y sus colonias fue de carácter irreversible: un punto sin retorno ${ }^{\circ} \mathrm{Y}$ no me refiero, exclusivamente, a las medidas de orden fiscal. En este sentido, es preciso enfatizar que el proceso de ruptura ro se inicia en 1808 sino bastante antes. El «desastre de

94 Minchom, Martin: La evolución demográfica del Ecuador en el siglo XVIII, "Culturaw, vol. VIII, núm. 24, 1986, para el caso de Quito. Con re!ación a la Intendencia cie La Paz, los porcentajes se basan en el artículo de Klein, Herbort: The structure of the bacendado class in the late eighteenth century Alto Perú: The Intesdencia of Ld Paz. "HAHR», núm. 60, 1980.

95 O'Phelan Godoy: Un siglo de Rebeliones Anticoloniales, pág. 175. Este argumento to plan. tee, con anterioridad, en el articulo La rebelión de Túpac Amaru: orgunización interna, dirigencia y alienzas, (1979). Para un tratamiento similar en el chso del Ecuador, consúltese la disertación de Douglas Alan Washburn: The Bourbon Reforms; i social and economic bistory of the Audie.1cia of Quilo, 1760-1810. Tesis de Ph. D. Universidad de Texas en Austin, 1984. 
1808», como lo denomina Anna ${ }^{\text {«n, }}$, sólo refuerza una crisis que ya estaba en marcha.

Resulta entonces más conveniente hablar de demandas irresueltas. Las reivindicaciones que se esgrimieron en los programas del XVIII pero que no se viabilizaron, reaparecen en el temprano XIX: abolición !de monopolios, reducción de impuestos, reblandecimiento del reglamento del comercio libre, expulsión de los peninsulares que conforman el nuevo sparato burocrático y administrativo, revalorización de los privilegios del clero y la Iglesia, recorte de los impuestos eclesjásticos $^{27}$.

El grito de «Viva el Rey, Muera el Mal Gobierno» que surge en 1780-1781, se transforma en «Viva la Independencia, muerte a los gachupines» o «muerte a los chapetones». La campaña en favor de la erradicación de los peninsulares no se inicia en 1810. En 1809, La Paz y Quito piden que los españoles que no quieran someterse a las juntas abandonen el virreinato o, de lo contrario, juren reconocimiento al nuevo gobierno.

Esto, a pesar de haberse decretado que «españoles» eran todos los habitantes de las colonias, sin distinciones étnicas. E! propósito de tal medida fue diluir los antagonismos y limar las diferencias frente al poder peninsular. Pero el sentimiento anti-peninsular no era nuevo $y$, además, se había agravado con la puesta en práctica de las reformas borbónicas y la transferencia de un nuevo cuerpo burocrático, administrativo y militar, a las colonias ${ }^{98}$. Así, el repudio al peninsular aparece consistentemente en las rebeliones del siglo XVIII, materializándose en ataques contra visitadores, aduaneros, corregidores. Quizás la diferencia radique en que, en el temprano XIX,

96 Anna, Timothy: España y la Indeperdencia de América, México, 1986, pág. 73.

97 O'Phelan Godoy: Por el Rey, Religión y la Patria, págs. 79, 80

98 O'Phelan Godoy: El mito de la independencia concedida: los programas políticos del siglo XVIII y el temprano XIX en el Perú y el Alto Perú. 1730-1814, en Flores Galindo, Alberto (ed.): Independencia y Revolución. Lima, 1987, pág. 179. Los antagonistios con los peninsulares y europeos. Pierre Vilar apunta esta atmósfera de xenofobia en su articulo La tarficipación de las clases populares, págs. 205-208. 
adquiere connotaciones más políticas: los criollos llegan a capturar el poder.

Pienso que la expulsión de los jesuitas, en 1767, pudo azuzar el conflicto. Obligar a numerosos clérigos criollos miembros de la Compañía a abandonar su tierra natal ${ }^{*}$, debió resultar contraproducente a las élites locales, creándoles una mayor conciencia de que debían hacer respetar sus derechos ante el gobierno colonial. No obstante, la erradicación de la Compañía de Jesús era el ataque selectivo a una orden y no una agresión frontal a la Iglesia como institución.

Así, si bien en el siglo XVIII caciques y curas demostraron su poder de convocatoria, los primeros y no los segundos serán la cabeza visible de las rebeliones. En el caso de la gran rebelión, los clérigos que de alguna manera se ven comprometidos en el movimiento forman parte del círculo cercano a Túpac Amaru; son sus compadres, porque o bien han casado al cacique o a sus familiares, o han bautizado a sus hijos. Son los doctrineros locales y serán señalados como los autores de algunas proclamas "plagadas de citas bíblicas» ${ }^{101}$. En el caso de Nueva Granada, la posición del clero será de reconciliación, un poco a imitación de la actuación del arzobispo don Antonio Caballero y Góngora. Sin embargo, es posible detectar la presencia subrepticia de algunos curas franciscanos, dominicos y agustinos que serán acusados de haber redactádo pasquines y oficiado misas por el éxito de los Comuneros ${ }^{101}$. Esta intervención se produce a pesar de que las Capitulaciones de Zipaquirá pondrán énfasis no sólo en los abusos de los corregi-

\footnotetext{
99 Lynch, John: The origins of Spanish America Indcpcndence, cn Leslie Bethell (ed.); The Independence of Latin America, Cambridge, 1987, pág. 8. De los 680 jesuitas expulsados de México, 450 eran mexicanos. De los 360 expulsados de Chile sólo un $25 \%$ erin peninsulares. 100 Lewin: La rebelión de Túpac Amaru, pág. 238. Véase también mi libro, Un siglo di rebeliones anticoloniales, págs. 241, 242 y el cuadrc núm. 26 en la pág. 238.

101 Aguilera Peña: Los Comuneros, pág. 100. Se nueı ciona el caso del dominico Fray Ciriaco de Archila, como autor de un pasquín, la presencia de un franciscano apellidado Villamizur, quien actuó como espía, y de dos agustinos de la locilidad de Tunja. Se trata, de miembros de la baja jerarquía eclesiástica, al igual como ocurre con los doctrineros de las parroquias cusqueñas durante la gran rebelión.
} 
dicres, sino también en los excesos perpetrados por los curas con los cobros por obvenciones ${ }^{102}$.

Por el contrario, al doblar el siglo, y después de que la Iglesia recibe el impacto de la política anticlerical de los Borbones, el clero participará más abiertamente en las luchas de independencia. El clero sufre su primer revés, en 1767, al dictaminarse la expulsión de los jesuitas. Pero, lo que determinará su distanciamiento de la metrópoli y su permeabilidad a la causa patriota será el secuestro de las capellanías y obras pías decretado, en 1804, por la Corona española ${ }^{103}$. De allí en adelante los eclesiásticos tendrán menos reparos en congregar tropas, redactar manifiestos, legitimar insurrecciones $\mathrm{y}$, además, dar estabilidad a los movimientos rebeldes. Dejarán !cs entretelones para asumir el liderazgo político ${ }^{10-4}$.

\section{Ei clero: del perfil bajo al protagonismo}

Pero la figuración del clero tiene antecedentes. En Nueva Granada, es el arzobispo-virrey Caballero y Góngora quien negocia con los Comuneros, en 1781, su repliegue de la escena política, además de asumir la misión de pacificar el alzamiento $^{10 \%}$. Creo que su éxito se debió más a su condición de arzobispo que a su puesto interino de virrey. En 1809, en

102 Friede: Rebelión Comunera, Tomo I, pág. 80, punto 7 de las Capitulaciones.

103 Lynch: The origins of Spanish American Independence, pág. 12 El clecreto de consolidación se puso en práctica el 26 de diciembre de 1804.

104 David Brading, en su libro Los origenes del Nacionalismo Mexicano, México, $1 ; 73$, escribirá «El vínculo que unía a esta variada mezcla de razas y clases era más el catolicismo que una conciencia de nacionalidad». Para el caso del Perú merece especial mención la disertación de Sparks, Consuelo: The role of the clergy in the struggle for Independence in Peri, tesis de Ph. D., Universidad de Pittsburg, 1972. Para Ecuador una obra clásica y de imprescindible consulta es el libro de Julio Tovar Donoso: La Iglesia, moderadora de la nacionalidad, Quito, 1953. Un enfoque similar se propone en el libro de Marie Danielle Demelas e Yves SaintGeours: Jerusalem y Babilonia. Religión y Politica en el Ecuador. 1780-1880. Quito, 1988.

105 Phelan: The People and the King, pág. 239. De acuerdo a Inés Pinto Escoivar: La rebelión del Común, pág. 100, el Arzobispo tuve grun éxito en su misión pacificadora. En el Socorro los moradores del barrio de Chiquinquirá sacaron en procesión la imagen de la virgen y lo fueron a buscar para pedirle que permaneciera en la villa. Estos actos se repitieron en las diversas villas y parroquias visitadas por Caballero y Góngora. 
Quito, el obispo José Cuero y Caicedo será elegido vicepresidente de la Junta Suprema que encabeza el marqués de Selva Alegre ${ }^{100}$. Se reproduce, en gran medida, el comportamiento de la élite quiteña durante la sublevación de los barrios de 1765: se reafirma la alianza entre patricios y clero. Esto no debe sorprender demasiado, en la medida de que numerosos clérigos eran también miembros del patriciado. No sólo :us intereses económicos y políticos, sino también sus lazos familiares confluían.

Pienso, además, que al decretarse el secuestro de las capellanías se propició un mayor acercamiento entre la élite y el clero, en la medida que era precisamente a partir de estos mecanismos «de caridad» como se fortalecían los vínculos entre la élite y la Iglesia ${ }^{107}$. La mayoría de los miembros de la élite tenían fundadas capellanías a favor de algún pariente cercatso que era sacerdote. Desmantelar estas conexiones sirvió para que aunaran sus esfuerzos en declarar su autonomía frente a España.

Así, en 1809 , Quito saca ventaja de la experiencia de los Comuneros con Caballero y Góngora, que sirve para demostrar el poder de negociación por parte del clero y lo que es más importante, su potencial para limar diferencias, para encontrar un punto de equilibrio, de consenso. La lección se aprende y es así como en 1809 , otro clérigo, José Cuero y Caicedo, será el elemento conciliador que catalizará las distensiones al interior de la élite, que enmendará el faccionalismo, que permitirá la supervivencia - frente a las amenazas de atomizaciónde la junta quiteña. Justamente debido a ello, pasará de su cargo de vice-presidente a asumir, en 1811, la Presidencia de la Junta Suprema.

106 Tovar Donoso: La Iglesia, págs. 265, 29-274.

107 Doris Ladd, en su libro The Mexican Nobility at Independence. 1780-1826, Austin, 1976, desarrolla ampliamente este tipo de conexiones. Consúltese también el artículo de María Elena Porras: La élite quiteña a mediados del siglo XVIII, «Quitumbe», núm. 7, Quito, 1990, pas. 44. 
En La Paz, en 1809, se concertará la participación del bajo clero provincial, como ocurrió veladamente en 1780-1781. Pero esta vez tres clérigos asumirán posiciones claves dentro de la Junta Tuitiva y uno de ellos, José Antonic Medina, cura de Sicasica, tendrá una actuación destacada ${ }^{108}$. A diferencia de Quito, los curas parroquianos no jugarán un papel activo en la expansión del movimiento, las doctrinas no serán focns de propagación, probablemente debido a la efímera permanencia de la junta altoperuana frente a la estabilidad de la quiteña. Además, el conato rebelde que se suscitó con antelación, el 25 de mayo en Chuquisaca, alertó al alto clero y a las autoridades peninsulares. De allí que las diferencias que surgieron entre el arzobispo Moxo y los doctrineros de Charcas debieron combinar el excesivo rigor que demostró el clérigo en la adjudicación de parroquias y su origen peninsular ${ }^{100}$. Se entiende entonces que la alta jerarquía eclesiástica fuera proclive a orquestar una vez más la represión, al lado de una élite atemorizada por el traumático recuerdo de la rebelión de Túpac Amaru y el desbordamiento de las masas indígenas.

\section{Caciques sin sucesiones}

La rebelión de Túpac Amaru puso a las autoridades españolas en guardia sobre la capacidad de convocatoria por parte de los caciques del sur andino. Y es que, no sólo la

108 Pinto, Manuel M.: La Revolución de la Intendencia de La Paz (1800-1810). La Faz, 1945. También consúltese el artículo da Humberto Vargas Machicado: Una versión inédila de la Revolución del 16 de julio, «Khana» núm. 27-28, 1959, págs 125.126. Los otros clérigos incluidos en la nómina de la junta paceña son Melchor de la Barra, cura de Caquiaviri; el presbítero Juan Manuel Mercado y el ex-mercedario Francisco Javier de Iturri y Patiño.

109 AGI, Charcas, 454. Se le acusa de haber tratado de establecer ael reyno del terror Se le conectaba con el «despótico, avaro y pérfido Godoy». Don Benito María Moxo tra catalán y había sido promovido a la Auxiliatura de M.cloacán ante de adjudicársele el Asrobispado de Charcas.

110 O'Phelan Godoy: Un siglo de rebeliones auticoloniales, pág. 229, cuadro 24. Juan Jcsé Vega, en su libro José Gabriel Túpac Amaru, Lima, 1969, y Jean Piel, en su libro Capitalisme Agraire au Perou, Paris 1975, establecen la división entre caciques ricos y menos ticos, argumentando que los primeros se mantuvieron realistas y los segundos fueron rebeldes. 
¿ran rebelión sino también la maquinaria represiva se montó en base a la colaboración de la élite indígena ${ }^{110}$. Pero, no bien sofocada la insurrección se suspendieron las sucesiones cacicales y sólo fueron mantenides en sus puestos aquellos aciques que habían materializado su apoyo a la causa realista ${ }^{111}$. La descomposición del sistema cacical era un hecho, y las provincias cusqueñas fueron las más expuestas a todo lipo de irregularidades ${ }^{\mathbf{1 1 2}}$.

La postura realista de los caciques altoperuanos en 1780-1781 explicará que no reclamen una actuación política más representativa en la junta de 1809 , donde incluso se propone la abolición de los cacicazgos ${ }^{113}$. Sólo en el caso del Perú se mantendrá en vigencia la figura del cacique como líder de importancia. Así, el cacique Toribio Ara, en Tacna, y Matıo Pumacahua, en Cusco, tendrán aún espacio en la estructura de la dirigencia, aunque supeditados al liderazgo criollo ${ }^{114}$. Las alianzas se redefinen y el radio de acción de los caciques se reduce. Son una élite en extinción.

Precisamente, Ara y Pumacahua son dos sobrevivientes cuya participación en las juntas de Tacna, en 1811 y Cusco, en 1814, puede haber respondido al interés de garantizar que sus cacicazgos se mantuvieran en vigencia, ante la amenaza de abolición. No obstante, se ven involucrados en las juntas de gobierno en diferentes momentos. Ara, antes de decretada la Constitución de Cádiz de 1812. Pumacahua, no sólo a dos años de haberse oficializado la constitución, sino en circuns-

111 Díaz Rementería: El cacique en el Virreinato del Perú, pág. 50, por la real orden de 28 de abril de 1783 la institución cacical quedaba extinguida. Pero, por real cédula del 9 de mayo de 1790 se ordenó respetar los cacicazgos y la costumbre sucesoria en aquellos caciques y descendientes que no hablan tomado parte en la sublevación.

112 O'Phelan Godoy: El sur andino a fines del siglo XVIII: cacique o corregidor, «Allmanchis Puthuringaw. Vol. XI-XII, 1978. Los caciqu: se se nombran y remueven constantemente, y se comienza a cobrar 50 pesos a quienes quieran adjudicarse el título. La presencia de caciq.tes advenedizos es un mal generalizado. Las sucesiones han perdido vigencia. Este tópico cstí más elaborado en mi ensayo Kurakas sin sucesiones (ms.).

113 Ponce Sanginés, C. y García, R. A. (eds.): Dorumentos para la Historia de la Revolución de 1809. Vol. III, La Paz, 1954, pág. 25. Véase timbién mi artículo Por el Rey, Relizión y la Patria, pág. 77.

114 O'Phelan Godoy: El mito, pág. 171. 
táncias en que Fernando VII ha retomado las riendas de la Corona española anulando, entre otras cosas, los alcances de la Constitución ${ }^{116}$.

Pero el papel de los caciques en las juntas de gobierno es marginal; no alcanza el protagonismo del siglo XVIII durante el cual, a partir de la solidaridad de numerosos caciques del sur andino, Túpac Amaru configura y expande su rebelión. Es a través de los caciques como se aprovisiona de hombres y de víveres. Para el siglo XIX Pumacahua estará en condiciones de aportar, en 1814, un contingente de 200 hombres de tropa. Su poder de convocatoria, para esas fechas, debió haberse visto reducido si consideramos que entre 1809-1810 envió refuerzos al ejército realista de Goyeneche para la represión de las juntas de $\mathrm{La} \mathrm{Paz}$ y Buenos Aires. Mientras tuvo aspiraciones de ubicarse en la Audiencia del Cusco —en la que llegó a detentar interinamente la presidencia - se mantuvo leal al gobierno peninsular. Fue al ser removido de la Audiencia cuando comprendió las limitaciones de su figuración bajo los cóćigos coloniales y aceptó participar en calidad de aliado en la Junta cuzqueña que, en 1814, constituyó un grupo de criollos provincianos encabezados por los hermanos Angulo.

\section{Los indios: de tributarios a «ciudadanos»}

Ni en Quito ni en La Paz se hablará, durante 1809, de la erradicación de mitas y tributos, argumento que sí se

115 Colección Documental de la Independencia del Perú (en adelante, CDIP), tomo IJI. Conspiraciones y Rebeliones en el, siglo XIX. La Revolución del Cuzco de 1814, Lima, 1971, págs. 310. Al ser preguntado Pumacahua por la razón de su prisión dijo «que es por la revolución que suscitaron los Angulo en la ciudad del Cuzco, quienes le hicieron creer que nuistro Soberano, el Señor Don Fernando VII habla fallecido en la prisión o actividad en que lo tuvieron los franceses $y$ que en este caso se hallaba de defender la Patria de cualquiera ctra dominación...». Pumacahua habla ejercido, brevemente, el cargo de presidente interino de la Audiencia del Cusco. Estaba, por lo tanto, bastanic compenetrado cor el espíritu de la constitución. 
ciiscutió en los programas del XVIII, aunque sin ser el foco central de los mismos ${ }^{11 \beta}$. Sólo la Constitución de 1812 retomará estas demandas, provocando el resquemor de la élite criolla que expresará la dificultad de seguir operando al margen de tales mecanismos de explotación colonial. Será en este momento cuando los indios presionarán porque se oficialice e! decreto de abolición del tributo y de las mitas ${ }^{117}$. No en vano uno de los objetivos del establecimiento de la junta cusqueña de 1814 fue, precisamente, la puesta en práctica de la Constitución, cuya aplicación había sido sistemáticamente retrasada por la Audiencia ${ }^{118}$. La junta que se instala en el Cuzco está conformada - a semejanza de la paceña- por criollos y mestizos que no pertenecen a la rancia élite provincial, pero que poseen propiedades y mantienen intereses comerciales ${ }^{119}$. De allí se entiende que al no ser los beneficiarios directos de tributos y mitas, abogaran por su supresión. Era también una manera de ganar consenso y aceptación entre la población india y de atraerlos al movimiento. Serán, en todo caso, los grandes propietarios los que teman la repercusión de la nueva legislación y su interferencia con el suministro de mano de obra in. dígena.

Es evidente que las discusiones en torno a la Constitución de Cádiz y a las elecciones de diputados y representantes locales debieron tener incidencia también sobie los pobladores indios. Pero ser partícipes de este activismo político no les era del todo nuevo. Debe tenerse en cuenta que los movimientos

116 O'Phelan Godoy: Por el Rey, pág. 80.

117 Archivo Histórico Nacional de Quito (en adelante, AHNQ), Presidencial, 472, vol. 4, año 1812. Riobamba, a diciembre 1. Oficio dirigido al presidente y capitán genteral de Quito por don Martín Chiriboga, Tomás Yépez, Mariano Davalos, Bernaitino Orosco, Baltazar de Puredes y otros, pidiendo a nombre del cabildo de Riobamba so ponga en práctica la absolución de tributos. Para el caso del Perú consúltese el artículo c'e Christine Hünefeldt: los indios $y$ la constitución de 1812, «Allpanchis Puthurinqa», núm. 11-12, 1978.

118 CDIP, tomo III. Prólogo de Horacio Villariuiva Urteaga.

119 Aunque Heraclio Bonilla se refiere a los lideres de la junta cuzqueña como umestizos y blancos pobres\%, he argumentado que todos posilan hrciendas y comerciaban con el Alto Perú, pagando alcabalas. Consúltese mi artículo El mito de la independencia concedida, pág. 195. 
del siglo XVIII de alguna manera fueron un medio de «politización», de «formación» para las masas indígenas. La convocatoria de la élite quiteña a Cabildo Abierto en 1765 fue acogida con entusiasmo por los pobladores de los barrios periféricos ${ }^{120}$. De igual manera, con el avance del movimiento Comunero a Bogotá, la elección de capitanes y redacción de las Cápitulaciones de Zipaquirá, se dio un espacio de representatividad política abierto no sólo a los criollos sino también, aunque en forma más reducida, a mestizos e indios ${ }^{121}$. Asimismo aunque Túpac Amaru designó directamente a sus comandantes y capitanes, Julián Apaza Túpac Catari promovió elecciones a nivel de las comunidades, cuyos dirigentes fueron nominados «por aclamación general» ${ }^{122}$. Esta atmósfera política de elecciones, representantes y reivindicaciones, debió producir alteraciones a nivel de las comunidades al hacer partícipes a las masas indígenas de la efervescencia del momento.

En un principio la junta paceña de 1809 convocará exclusivamente a la «acción de los cholos» de la ciudad, sin apelar a las comunidades indígenas ${ }^{123}$. Esto puede explicar que los pobladores indios, al verse postergados, hayan sido más proclives a la organización de guerrillas para poder expresar sus intereses y expectativas en el nuevo gobierno criollo ${ }^{134}$. Se aludirá a que Manuel Victorio García Lanza, uno de los miembros de la junta, estaba en condiciones óptimas para

120 McFarlane: The Rebellion of the Barrios, págs. 292, 293. El monopolio del aguardiente también involucraba a tenderos y pulperos nưtizos e indios, quienes se sumaron a las protestas.

121 Friede: Rebelión Comunera de 1781, tomo I, pág. 80. El séptimo punto de las Capitulaciones, atahe a las reivindicaciones solicitadas para la población indígena. Los primeros puntos se concentran en quejas contra las reformas fiscales borbónicas: las guías, alcabala de Barlovento, monopolio del aguardiente, y otros producivis estancados.

122 O'Phelan Godoy: Un siglo de rebeliones anticoloniales, pág. 262.

123 Abencia Baldivieso, Valentín: El criollismo de La Plata, La Paz, 1970, págs. 91, 94. Uno de los líderes de la plebe urbana será el nulato Irancisco Ríos, conocido como el capitán de los cholos y apodado «Quitacapas».

124 Sobre las guerrillas altoperuanas se puede consultar el libro de Arze Aguirre, Rane: Participación popular en la Independencia boliviana, La Paz, 1979.

Tomo $X I I X$ 
establecer comunicación con las comunidades, en consideración a que tenía propiedades en las Yungas ${ }^{12 \cdot}$. De esta manera se propiciaba la relación patrón-cliente, a la que también recurrirán los miembros de la junta quiteña. Así, Carlos y Xavier Montúfar (hijos del marqués de Selva Alegre) contaban, en Riobamba, con un centenar de indios de peonaje con palos, barretas y sacos, para formar parapetos ${ }^{126}$.

No obstante su participación «a medias» en las juntas, las demandas del campesinado indígena sólo serán oídas cuando se promulgue en 1812 la Constitución de Cádiz, que abolía tributos y mitas. En 1809 se había establecido que Hispanoamérica no era colonia sino parte integrante del Imperio cspañol y que todos sus habitantes debían ser considerados españoles. En los sucesivos autos judiciales que presenten los campesinos de las comunidades enfatizarán su estado de «españoles-indios» y «ciudadanos exentos de mitar» ${ }^{127}$. De allí que cuando, en 1814, Fernando VII retorne a España y trate de ciar marcha atrás frente a estas medidas, será muy difícil persuadir a las comunidades de que deben prescindir de los beneficios que la Constitución les había otorgado. De alguna manera dejar de mitar y de tributar fue interpretado como que «ya eran todos iguales ante la ley», aunque más temprano que tarde descubrirían que ser «españoles» no significaba, necesariamente, ser «ciudadanos».

125 Bedoya Ballivián, Mario: Manuel Victorio García Lanza, Lal Paz-Cochabamba, 1775, págs. 46, 47. Poseĺa tierras en el sector de Coroico: San Pablo, San Pedro, San Cristóbal, Carmen-pampa, Chobacollo, Yalaca, Calaama.

126 AHN, Consejos, 21.677.

127 Archivo General de la Nación (Lima) (en adelante AGN), Derecho Indígena, C746, año 1813. El alcalde ordinario del pueblo de Vischongos, Ayacucho, solicita se abstuviesen de que su comunidad mitara «en el Tambo de Cangallo, como ciudadanos exentos ...por la abolición gcneral del servicio forzado de los españoles-indios en la posta de Ocros y en todas las demás..." 
Las semillas de la autodestrucción: Kegionalismo y Faccionalismo

El regionalismo y el faccionalismo ${ }^{128}$, que han sido considerados rasgos distintivos de las luchas de independencia, presentan connotaciones particulares en el siglo XVIII. Con relación al primero se puede observar, por ejemplo, que las rebeliones del Perú y Nueva Granada se circunscriben a una región. Una región donde se articulan intereses económicos, redes comerciales, lazos familiares y en donde existe, en consecuencia, un margen para proyecciones políticas. En el caso del Perú, la gran rebelión se expande hacia Bolivia. Por otro lado, el movimiento Comunero se propaga hacia Venezuela. Si bien los epicentros son Cusco y Socorro, el entretejido que los sustenta compromete, respectivamente, a las provincias altoperuanas, y a Pamplona, en Venezuela ${ }^{123}$.

No obstante, no hay ecos militares ni de uno ni de otro movimiento en el caso de la Audiencia de Quito, escenario de la rebelión de 1765 . En todo caso, las autoridades peninsulares expresarán su inquietud de que, por su naturaleza similar, el movimiento Comunero pueda ganar adeptos entre la élite quiteña. Es evidente que hay más puntos de coincidencia entre la rebelión de los barrios y los Comuneros, que entre estos movimientos y la gran rebelión, donde la élite provincial se cuidará de no dar la cara. Pero si bien durante 1780 las reformas borbónicas causan revueltas locales en los pueblos adyacentes a Ambato, donde en Pelileo, Quisapincha, Píllaro y Baños se protesta contra los nuevos impuestos y se tscucha el grito de «Viva el Rey y muera el mal gobierno» ${ }^{30}$,

128 Sobre regionalismo tiene reflexiones interesintes el artículo de Fisher, John: Royalism, Regionalism and Rebellion in colonial Perú, 1808-1315, «HAHR», núm. 59, 1979. Sobre cl faccionalismo sigue en vigencia el análisis que propone Tulio Halperin Donghi en su ensayo $\mathrm{La}$ crisis de la Independencia, en «La Independencia del Perú», Lima, 1981.

129 Aguilera Peña: Los Comuneros, pág. 167. Una red de importante flujo comercial era la tendida alrededor del puerto de Maracaibo.

130 Moreño Yánez: Sublevaciones indigenas, págs. 251, 291.

Tomo $X L I X$ 
los enfrentamientos no trascienden del plano local, no se articulan ni en el norte con Nueva Granada, ni en el sur con el Perú. Quizás porque se trata, fundamentalmente, de revueltas indígenas, los criollos ya habían tenido su rebelión, en 1765 , y se mantendrán al margen de los altercados que propicien los indios contra los empadronamientos y el nuevo esquema de alcabalas que incorpora productos nativos que gozaban de excepción. Las revueltas de 1780 en la Audiencia de Quito mantienen, por lo tanto, un perfil insular.

No obstante, si bien geográficamente los movimientos sociales de este período tienen connotaciones regionales, no nacionales, las noticias se transmiten, la información circula y supera el ámbito de lo local. En Cusco, en 1780, los rumores sobre la rebelión de Quito de 1765 , señalan el éxito de los criollos. Farfán de los Godos exaltará a sus allegados refiriéndose a que en Quito, en sólo una noche y un día, se habían librado de pensiones y aduana quedando en vigencia sólo la alcabala y el tributo ${ }^{181}$. En Arequipa se arengará a la plebe recordándoles que «Quito y Cochabamba se alzó y Arequipa porqué no» ${ }^{102}$, En Nueva Granada se exige que se remitan copias de las Capitulaciones de Zipaquirá, no sólo a Popayán, Cartagena y Pasto sino también a Quito, en un intento por contar con un consenso regional ${ }^{188}$. Pero no existe un proyecto nacional, ni en el siglo XVIII ni en el temprano XIX. $\mathrm{El}$ marco de las rebeliones sigue siendo restringido, reduciéndose a aquella región que les resulta familiar a los insurgentes, no va más allá. La óptica es limitada, subyace el sentimiento de lo «patria chica», es decir, del lugar de origen, de residencia. A lo sumo se expande al lugar de tránsito, de contacto, aunque siempre se trate de un contacto regional.

En 1809, el virrey Abascal es de alguna manera el eje de un aparato represivo que trasciende los límites regionales,

131 Angles Vargas: El cacique Tambobuacso, pág. 81.

132 AGI, Lima, 1.052. 'Declaración de don Antunio Jooet Lastarria, vista de la Real Aduuna.

133 García, Antonio: Los Comuneros, 1781-1981, Bogotá, 1986, pág. 128. 
al tener que sofocar simultáneamente, dos insurrecciones: las de Quito y $\mathrm{La} \mathrm{Paz}{ }^{194}$. Su objetivo militar amplía el marco de agitación social y política. Su radio de interés no fragmenta el sur andino del escenario de la Junta quiteña; los visualiza en conjunto. El marco regional se ensancha, pero a su vez se jimita, exclusivamente a la fronteras espaciales del virreinato del Perú en el momento previo al desmembramiento de las Audiencias de Quito y Charcas. No obstante, los programas políticos se restringen al contexto regional y reflejan, sobre todo, los intereses de las élites provinciales.

La naturaleza del faccionalismo es también distinta en las rebeliones del XVIII. La división que establece Aguilera Peña para el caso de Socorro entre capitanes terratenientes y capitanes populares se pondrá también de manifiesto en el temprano XIX y desembocará en la conformación de facciones. Sin embargo, en el XIX el faccionalismo surgirá y, en forma más transparente, a nivel de la élite. El caso de Quito es el más ilustrativo si consideramos que se gestaron al interior de la Junta Suprema dos facciones: la del marqués de Selva Alegre y la del marqués de Orellana ${ }^{135}$.

Pero cabe también establecer diferencias. En el XVIII las facciones de capitanes terratenientes y capitanes populares (distinción que también se puede ajustar al caso del Perú en la presencia de Túpac Amaru y Túpac Catari), no llegaron a enfrentarse militarmente. Hay momentos de descoordinación entre los ejércitos quechua y aymara, no sólo porque los objetivos no siempre coinciden sino por problemas de incomunicación verbal que determinan la necesidad de recurrir a intérpretes. Pero muchos de los movimientos militares son planeados en conjunto: Túpac Catari tiene una autonomía relativa, el comando central estará en las manos del clan Túpac Ama-

\footnotetext{
134 Hamnett, Brian: Revolución y contrarrevolución en México y el Perú, México, i978, págs. $33,58,59$.

135 Torre Reyes, Carlos de la: La Revolución de Quito del 10 de agosto de 1809. Quito, 1961, púg. 630. Los Sanchistas y los Montufaristas se tornaron irreconciliables, siendo los sintemas de deterioro evidentes en mayo de 1811.
} 
${ }^{\text {ru }}{ }^{138}$. Por el contrario, en el XIX las facciones chocan y en el caso de Quito, sólo la presencia del obispo Cuero y Caicedo logra conciliar lo que se estaba convirtiendo en una guerra civil entre montufaristas y sanchistas.

Regionalismo y Faccionalismo persistirán durante las guerras de independencia y serán dos de las grandes trabas que encuentre Bolívar para mantener la estabilidad de la Gran Colombia. Pero sus raíces son coloniales, exacerbadas por !as reformas borbónicas. No en vano la conformación de los nuevos estados republicanos guardará límites similares a las tradicionales Audiencias coloniales: Quito (Ecuador), Lima (Perú) y Charcas (Bolivia). Asimismo, regionalismo y faccionalismo serán vértice del caudillismo, que obstaculizará la estabilidad política de los nacientes estados durante el temprano período republicano.

Scarlett O'Phelan Godoy

136 O'Phelan Godoy: Un siglo de rebeliones anticoloniales, pág. 259. 